NBER WORKING PAPER SERIES

ASSET SALES, FIRM PERFORMANCE,
AND THE AGENCY COSTS OF
MANAGERIAL DISCRETION

Larry Lang

Annette Poulsen

René M. Stulz

Working Paper No. 4654

\author{
NATIONAL BUREAU OF ECONOMIC RESEARCH \\ 1050 Massachusetts Avenue \\ Cambridge, MA 02138 \\ February 1994
}

\begin{abstract}
We are grateful for useful comments from David Brown, Gailen Hite, Ravi Jagannathan, Michael Jensen, David Mayers, Robert McCormick, Craig Lewis, Jeffry Netter, Tim Opler; Eli Ofek, an anonymous referee, participants at seminars at Clemson University, New York University, the University of Michigan, the WFA meeting in San Francisco, the AFA meetings in Anaheim, and especially Harry DeAngelo. This paper is part of NBER's research programs in Asset Pricing and Corporate Finance. Any opinions expressed are those of the authors and not those of the National Bureau of Economic Research.
\end{abstract}


NBER Working Paper \#4654

February 1994

\title{
ASSET SALES, FIRM PERFORMANCE, AND THE AGENCY COSTS OF MANAGERIAL DISCRETION
}

\begin{abstract}
We argue that management sells assets when doing so provides the cheapest funds to pursue its objectives rather than for operating efficiency reasons alone. This hypothesis suggests that (1) firms selling assets have high leverage and/or poor performance, (2) a successful asset sale is good news and (3) the stock market discounts asset sale proceeds retained by the selling firm. In support of this hypothesis, we find that the typical firm in our sample performs poorly before the sale and that the average stock-price reaction to asset sales is positive only when the proceeds are paid out.
\end{abstract}

\author{
Larry Lang \\ Department of Economics \\ New York University \\ 269 Mercer Street, 7th Floor \\ New York, NY 10003 \\ René M. Stulz \\ College of Business \\ The Ohio State University \\ 1775 College Road \\ Columbus, $\mathrm{OH} 43210$ \\ and NBER
}

\author{
Annette Poulsen \\ Department of Economics \\ University of Georgia \\ Athens, GA 30602-6251
}




\section{Introduction.}

Existing empirical evidence shows that asset sale announcements are associated with positive stock-price reactions. Alexander, Benson and Kampmeyer (1984), Hite, Owers and Rogers (1987) and Jain (1985) document significant average abnormal retums between $0.5 \%$ and $1.66 \%$. A theory advanced in the literature to explain this empincal evidence, most explicilly by Hite, Owers and Rogers (1987), is that asset sales promote efficiency by allocating assets to better uses and sellers capture some of the resulting gains. With this view, which we call the efficient deployment hypothesis of asset sales, firms only manage assets for which they have a comparative advantage and sell assets as soon as another firm can manage them more efficiently.

In this paper, we provide empirical results inconsistent with the efficient deployment hypothesis and advance an altemative explanation for asset sales consistent with our new results. First, we show that firms selling assets tend to be poor performers and/or have high leverage. In particular, for our sample, median net income nomalized by total assets is insignificantly different from zero in the year before the sale, even though we exclude from the sample bankrupt firms and firms in defautt. This result suggests that the typical firm selling assets is motivated to do so by its financial trouble rather than by the discovery that some other firm has a comparative advantage in operating the assets. Second, contrary to the efficient deployment hypothesis, we find that the stock-price reaction to successful asset sales is strongly related to the use of the proceeds. In our sample, the stock-price reaction to asset sales is positive for those firms expected to use the proceeds to pay down debt but negative and insignificant for firms which are expected to keep the proceeds within the firm.

We argue that our results are inconsistent with the efficient deployment hypothesis because asset sales are undertaken by management which pursues self-serving objectives and 
views asset sales as a source of funds. We call this altemative hypothesis the financing hypothesis of asset sales and show that it is supported by our empirical results. If management values firm size, diversification or its reputation, one expects it to be reluctant to sell assets for efficiency reasons alone.' For such management, a more compelling motivation to sell assets is that asset sales provide funds when altemative sources of financing are too expensive, possibly because of agency costs of debt or because information asymmetries make equity sales unattractive. With this view, the completion of an asset sale is good news about the value of the asset because if the value of the asset had tumed out to be low, the sale would not have taken place. Moreover, when agency costs of managerial discretion are high, one expects the market to discount proceeds of asset sales retained by the firm.

Section 2 provides a theoretical analysis of the information content of asset sales. Section 3 presents our sample of large asset sales and reports the characteristics of the firms in our sample. Section 4 shows that abnomal retums associated with asset sale announcements differ substantially between firms that have performed poorty and use the proceeds to repay debt and those that do not. Section 5 uses cross-sectional regressions to explore the robustness of our main results. Concluding remarks are presented in section 6.

\section{Section 2. The Information content of asset sales.}

Part 2.1 discusses the information content of asset sales in the absence of agency costs. Part 2.2 presents the financing hypothesis. Finally, part 2.3 collects our testable hypotheses and relates them to the existing empirical evidence on asset sales.

\footnotetext{
'Boot (1992) and Weisbach (1993) argue that management postpones asset sales because abandoning an unsuccessful strategy impacts the market's assessment of managers' ability. Weisbach (1993) shows that divestitures are concentrated around management changes.
} 


\subsection{The efficlent deployment hypothesis.}

We assume in this subsection that: (A1) management maximizes shareholder wealth, (A2) the transaction costs of selling assets are greater than those of issuing new securities, and (A3) low risk debt financing is available. With these assumptions, management sells an assel if the price the purchaser is willing to pay exceeds the asset's value in its current use. A firm may leam over time that it is not well-suited to operate an asset and seek to sell it or some other firm may find out that it could operate the asset more profitably and attempt to buy it.

With our assumptions, an asset sale announcement has a positive stock-price reaction if, before the announcement, the market has an unbiased estimate of the asset's value in its current use and investors are surprised by the announcement that the asset is worth more to somebody else. The stock-price reaction for a specific sale could be negative because the market is disappointed with the price fetched by the asset. If investors know that the firm is trying to sell an asset, however, the expected stock-price reaction is zero if the market's expectation of the sale price is unbiased. If a firm knows that other firms can obtain greater cash flows from an asset and the market for assets is competitive, it will sell the asset even if it finds out that the asset is worth less than expected because the asset is nevertheless worth more outside the firm. Finally, with the efficient deployment view, the use of the proceeds does not matter unless it conveys information about the availability of positive NPV projects. In this case, retention of the proceeds is good news because management which maximizes shareholder wealth would pay out the proceeds if it did not have positive NPV projects available.

\subsection{The financing hypothesis.}

We now consider the case where a firm is trying to raise funds to pursue managerial objectives which need not be consistent with shareholder wealth maximization. We assume that 
the firm cannot sell low risk debt because it has high leverage and/or poor performance. Outsiders know that the firm wants to raise funds. Such a firm may find it expensive to use the capital markets for at least three reasons. First, it may face the underinvestment problem described by Myers (1977) or the asset substitution problem analyzed by Jensen and Meckling (1976). Second, raising outside funds may be costly because of the adverse selection costs modeled by Myers and Majluf (1984). Third, the cost of outside funds may be high because of agency costs of managerial discretion. in particular, if management may use funds to pursue objectives of doubtful value to capital providers, they require a higher promised rate of retum or restrictions on the use of funds.

For management, asset sales may provide a source of funds preferable to capital markets even with high transaction costs. First, informational asymmetries may be less important for the asset the firm wants to sell than for the firm as a whole. Second, selling an asset may avoid the recapitalization costs that would have to be paid to raise funds on capital markets if the debt overhang is large. Third, if management pursues its own objectives, selling an asset provides funds with potentially fewer restrictions on managerial discretion.

If a firm sets out to sell an asset to obtain cheaper funds than on capital markets, it may fail. With uncertainty about the asset's value to outsiders, the sale price the firm can obtain after shopping the asset may be too low to justify selling it. This could be because the asset is worth too little to outsiders relative to its value in its current use. Alternatively, as emphasized by Shleifer and Vishny (1992), the market for an asset may not be liquid, so that a quick asset sale may require a large discount. Hence, if the firm succeeds in selling the asset at a price which makes the transaction worthwhile, this is good news about the asset's value even if it is known that the firm wants to sell the asset. This is in contrast to the efficient deployment view where planned sales always take place and hence their completion conveys no news on average. 
If the intended use of the proceeds is a positive NPV project for the shareholders and if the firm does not have a more advantageous source of funds, a successful asset sale means that the firm can carry out the positive NPV project with the cheapest funds. For a firm in distress, this project might be to pay back debt to avoid default. Alternatively, for a firm suffering from the underinvestment problem, it may mean taking advantage of a valuable investment opportunity. Hence, for firms with good projects for which an asset sale offers the cheapest financing, the announcement of a successful asset sale is good news about the ability of the firm to invest.

For some firms, however, the proceeds from the sale could be put to uses that do not increase shareholder weath. In this case, the good news about the value of the asset sold is tempered or negated by the market's expectation that some of the proceeds will be wasted by management. For instance, a firm with core operations that suffer massive losses and should be changed dramatically may sell assets to finance these losses to avoid making necessary changes. Hence, for firms where agency costs of managerial discretion are important, the stock market views asset sales where the proceeds are paid out to debtholders or shareholders more favorably than those where the proceeds are kept within the firm.

So far, we have assumed that the stock market knows that management lacks funds to pursue its objectives. If this is not the case, the first announcement concerning an asset sale can convey information about the firm's financial heath. This effect is similar to the one discussed by Miller and Rock (1985) for the case where a firm sells securities. In this case, since the firm would not be raising funds if its eamings were higher or if it could get attractive terms on financial markets, the first announcement regarding an asset sale provides negative information about the firm's financial situation unless it is accompanied by news about valuable investment opportunities. 


\subsection{Testable hypotheses.}

We can summarize our hypotheses and their empirical implicalions as follows:

1. Efficlent deployment hypothesls. a) Unanticipated asset sales improve shareholder wealth on average. b) Proceeds retained by the firm are discounted by the stock market.

2. Financing hypothes $(s$. a) Firms sell assets when doing so is the cheapest source of funds given management's objectives. In particular, asset sales take place for firms that cannot raise funds cheaply on capital markets, e.g., highly levered and/or poorly performing firms. b) Successful asset sales convey good nows about the value of the assets sold. c) With significant agency costs of financial discretion, the market discounts the proceeds from asset sales retained by the firm. With the financing hypothesis, a potential confounding effect is that the asset sale may reveal information about the financial situalion of the firm or about investment opportunities.

The financing hypothesis has no implications about the relative efficiency of the buyer and the seller in operating the asset sold. Hence, it does not preclude that the asset sold goes to a user with a comparative advantage in operating it. With the efficient deployment view, however, management always compares the productivity of assets under its control to the productivity the assets would have if sold and sells an asset whenever it loses its comparative advantage in operating it. Hence, management's reluctance to sell assets (see Boot (1992) and Weisbach (1993)) is evidence against the efficient deployment view. With the financing hypothesis, management is pushed to sell assets by the firm's financial situation. Assets are not sold for efficiency reasons alone, so that managers of some firms keep assets for which the firms have no comparative advantage and make no aftempt at selling them as long as the firm's financial situation is good enough. Obviously, in some cases, the firm's financial situation is such that it becomes an attractive takeover target, which leads management to sell assets it operates inefficiently so that it can retain its position. 
With the efficient deployment view, the use of the proceeds should not matter. In contrast, with the financing view, proceeds paid out to debtholders or shareholders are valued more if agency costs of managerial discretion are significant. The only empincal evidence we know of that distinguishes among uses of proceeds is provided by Brown, James and Mooradian (1993) and Mayers and Singh (1993). Brown, James and Mooradian (1993) focus on a sample of firms in severe distress, most of thern in default. They find that asset sales where the proceeds are used to pay back creditors affect shareholders adversely, indicating that, for firms in default, asset sales are made to benefit creditors rather than shareholders.

Mayers and Singh (1993) look at announcernents of asset sale programs as well as at announcements of completed asset sales. When a firm announces that it intends to sell assets, there is little or no information released about the sale price of assets. Hence, outsiders mostly leam that the firm wants to raise funds and the proposed use of the funds. Mayers and Singh (1993) find that the proposed information is important to the stock market. They find a large positive stock-price reaction when the firm announces that it intends to use the proceeds to finance a stock repurchase; a positive significant announcernent effect when the firm intends to re-invest the proceeds and a negative effect when the firm intends to repay debt. The magnitudes of the effects they observe seem to be similar to the stock-price reaction one would observe if these announcements were not accompanied by the announcement of asset sale programs: stock repurchase announcements have large positive effects, announcements of investments have small positive effects, and announcernents of leverage decreases have small negative effects. ${ }^{2}$ At the time of the completion of the sale, the market leams only that the sales price is large enough for the sale to succeed since the firm announced eartier the intended use of the

\footnotetext{
${ }^{2}$ See McConnell and Muscarella (1985) for a study of announcements of investments and Smith (1986) for a review of the stock-price reactions to financing announcements.
} 
proceeds. One would therefore expect the sales announcement effect to be positive when firms announce the completion of an asset sale, which is what they find.

\section{Section 3. Characteristics of large asset sales and of the firms that make them.}

\section{Section 3.1. The sample.}

In this paper, we investigate asset sales reported to the SEC in 8K forms as identified through the NEXIS database.' NEXIS reports all BK filings from October 1988 but only selected abstracts are included from 1985 through October 1988 . The $8 \mathrm{~K}$ form requires that the registrant fumish specific information if it or "any of its majority-owned subsidiaries has acquired or disposed of a significant amount of assets, otherwise than in the ordinary course of business." Hence, asset sales reported in 8K forms are ideally suited to address the issues raised in this paper since the firm deems the sale to be both significant and unanticipated.

We identify 151 asset sales taking place from 1984 to 1989 for firms for which data is available on the Compustat files. We want to study voluntary asset sales and therefore eliminate firms that are in default, in a corporate control contest, in voluntary or involuntary liquidation or have filed for reorganization under Chapter 11. Further, we omit all asset sales of less than $\$ 1$ million. Finally, we eliminate all firms for which stock retums could not be found on the CRSP files for NYSE and AMEX stocks. Of the 151 asset sales, 93 sales made by 77 firms satisfy our additional criteria. The Appendix provides detailed information on each sale in our sample; the reader can refer to this appendix when we mention specific sales in our discussion. The average number of asset sales per year (15.3) in our sample is substantially smalier than in the Jain (1985) sample, but substantially lareer than in the Alexander, Benson and Kampmeyer (1984) and Hite, Owers and Rogers (1987) samples. We use as the announcement date the earliest of the

\footnotetext{
"The NEXIS search used the key words "asset" within 10 words of "sale" and "divestitures."
} 
following three dates: (1) the Wall Street Joumal (WSJ) announcement date (44 cases); (2) the Dow Jones News Retrievat Service announcement date (25 cases); (3) the agreement date as reported by the $8 \mathrm{~K}$ filing ( 24 cases).

Since we are interested in the differences between firms expected to pay out the proceeds and those that are not, we use information from the 8K flings, annual reports, the S\&P Standard Stock Reports and the WSJ to determine why the asset was sold and how management expects to use the proceeds. The sample has 40 asset sales by 35 firms with proceeds paid out to creditors and/or shareholders and 53 sales by 43 firms (one firm makes one sale of each type) with proceeds retained by the firm. We call this sample of 40 sales the "payout sample," and the sample of 53 sales the "re-invest" sample throughout the paper. For 22 asset sales by 18 firms where the proceeds are paid out, information about the use of the proceeds is given by the $8 \mathrm{~K}$ filing or the press articles contemporaneous with the ennouncement. Of these 22 sales, there are 12 cases where the source for the announcement date is the WSJ or the Dow-Jones Wire and the use of funds is given in the WSJ and 4 cases where the announcement date is the date of the $8 \mathrm{~K}$ filing and the $8 \mathrm{~K}$ form gives the use of funds. Though we generally focus on the 40 asset sales where the proceeds are paid out, we report confirming abnormal retums evidence for these 16 sales in table 5 since they correspond to our cleanest subsample where investors leam simultaneously about the sale and the use of the proceeds. For the other 18 asset sales where the proceeds are paid out, our sources describing the use of funds are not contemporaneous with the sale announcement. These sources are the annual report (12 times), an $8 \mathrm{~K}$ filing subsequent to the announcement date (4 times) or the S\&P Standard Stock Reports (2 times).

In general, we rely on the full sample of firms paying out the proceeds because we presume that investors have rational expectations at the time of the asset sale announcement, in the sense that, on average, they expect the proceeds to be paid out when a subsequent 
announcement to that effect is made. To the extent that the probability that such a statement will be made is less than one, the effect of the planned use of the proceeds on the announcement of the sale is reduced and our tesis are less powerful. There is no noticeable difference for the source of the announcement date between the sample of firms that pay out the proceeds and the sample of firms that do not. In both samples, roughly $75 \%$ of the observations come from the Dow-Jones Wire and the WSJ. Hence, the difference in the stock-price reactions between the two samples cannot be attributed to a difference in how investors leam about the event.

If the financing hypothesis applies to the sales in our sample, one would expect the proceeds paid out to be used to pay down debt rather than to distribute cash to shareholders. If a firm is excessively levered in management's eyes, management has a strong motivation to sell assets to reduce leverage and avoid possible costs of financial distress. In contrast, if most proceeds were used to pay dividends to shareholders in the absence of pressures from the market for corporate control, one would view this evidence as consistent with the absence of agency costs of managerial discretion and supportive of the efficient deployment hypothesis where management pays out to shareholders funds it cannot invest profitably within the firm. We have only five cases where there is evidence that management plans to pay some of the proceeds to shareholders: Allied-Signal, Culbro Corp, Federal Mogul, Koppers Co, and Union Carbide. Since we have only five observations where shareholders receive some of the proceeds directly, there is little we can say in this paper about the stock-price reaction difference between paying the proceeds to shareholders and using the proceeds to pay down debt. Although we include these observations in the payout sample, the results in this paper do not depend on these five observations.

Even though there is no indication that management expects to pay out part of the proceeds to shareholders, there could still be an indirect connection between asset sales and 
payouts to shareholders. For instance, management could sell assets to replenish liquid assets used for repurchases or to repay debt incurred to finance share repurchases; altematively, it could change its mind about the use of the proceeds after the sale and repuchase shares. A careful reading of the case histories provided in the appendix shows that the evidence in favor of an indirect connection is limited. After the sale, only two firms not paying out proceeds, John Fluke and Varo Inc., announce that they will undertake a stock repurchase. For 10 firms paying out proceeds, there are repurchase announcements in the year before the sale. Six of these repurchases are targeted repurchases where the company buys out a major shareholder, which raises suspicion of entrenchment.

There is some indication, though, that dividend payments may be affected by asset sales in our sample. Irrespective of the use of the proceeds, approximately twice as many firms increase dividends in the year after the sale as they do in the 12 months before the sale (5 relative to 3 for firms that pay out proceeds and 11 relative to 5 for those that do not). Two firms that pay out the proceeds decrease dividends in the 12 months before the sale and one in the following 12 months; in contrast, 3 firms that retain the proceeds reduca dividends in the year before the sale and one in the year following.

In our sample, firms provide a number of different reasons for selling assets. In some cases, they sell assets explicitly to reduce debt. In other cases, they give other reasons to sell assets but still pay out the proceeds. If a firm selis an asset and pays out the proceeds, though, the asset saie typically reduces the firm's diversification and if the asset is an unrelated division it necessarily does so. Hence, to understand the effect on shareholder wealth of the motivation of a sale, it is better to focus on the case where the proceeds are retained by the firm so that the effect is not confounded by the disbursement of proceeds effect. For the 53 sales made by firms which do not plan to pay out the proceeds, the following reasons to undertake the sales are given 
for at least five sales in our sample:

1. Focusing on core businesses. For instance, Wamer Communications Inc sold Franklin Mint in 1984 because this business was not part of its core businesses. In total, we have 15 firms (21 asset sales) where this motivation is prevalent.

2. Selling unprofitable or slow-growing businesses. An example of this would be the sale of United Inns Inc's car wash business in 1988 for $\$ 17$ million. Thirteen firms (14 asset sales) fit this expianation.

3. To finance acquisitions or expansion. Primark Corp sold its TV leasing business for \$ 37.9 million in 1988 to generate cash for a pending acquisition. This explanation seems appropriate for 6 firms (9 asset sales).

With the financing hypothesis, asset sales by firms focusing on core operations or selling unprofitable operations have a different impact on shareholder wealth depending on whether the proceeds are retained by the firm or not. For instance, it could be that a firm chooses to sell assets to finance losses on core businesses and postpone value-increasing changes in these businesses, in which case the proceeds of asset sales made to focus on core activities would be discounted by the stock market. Later, we provide evidence that asset sales made to focus on core activities or to shed unprofitable businesses do not significantly increase shareholder wealth in our sample when the proceeds are retained by the firm.

It is noteworthy that many companies seem to sell assets while engaged in a program of acquisitions so that the asset sales provide cash for these programs, even though management may motivate the asset sale using different considerations, such as eliminating unprofitable divisions or focusing on core activities. These cases are certainly consistent with the view that management might be raising funds to pursue its own objectives. An example of such a sale is the sale by Canal Capital Corp of its stockyard business for close to $\$ 7$ million in 1989. The 
annual report mentions that the stockyard business was not profitable; but at the same time the firm had moved (according to its annual report) from a stockyard firm to a diversified firm interested in real estate development, trading securities and investing in ancient ant!

\section{Section 3.2. Firm characteristics.}

In table 1, we provide data on the 93 asset sales and the firms that made them for the full sample and also on the basis of the use of the proceeds. In the following analysis, we discuss how the characteristics of firms that pay out the proceeds differ from those of other firms. Although we report both means and medians, we focus on the medians because the sometimes large difference between means and medians indicates that the distribution of the variables is not symmetric and hence the medians are likely to be more informative about the typical sample firm. The median asset sale in our sample represents $23 \%$ of the value of the selling firm's equity. There is a significant difference (at the 0.01 level) between the median sale proceeds as a fraction of the equity value for firms that pay out proceeds $(42 \%)$ and the other firms $(13 \%)$. We investigate later whether the difference in abnormal retums between firms that pay out proceeds and those that do not is due to differences in the magnitude of the sale relative to equity and find that this is not the case. The difference in the size of the sale relative to equity is partly due to the fact that the median market value of equity for the firms that retain the proceeds is higher than for the firms that do not. There is no significant difference, however, between the median book values of total assets of the two groups of firms. Finally, we report the average accounting gain or loss on sale, which turns out to be small for the typical firm irrespective of the use of the proceeds.

Firms in the payout sample have a lower average and median interest coverage ratio than firms in the re-invest sample. The median coverage ratio of firms that pay out the proceeds is 


\section{Table 1}

Firm eharacteristics for a sample of 93 signifieant asset sales

The sales are obtained from inspection of BK forms. Managerial ownership is obtained from proxy statements. The accounting loss on the sale is from the $8 \mathrm{~K}$ form. All other data is obtained from Compustat and CRSP tapes. The Compustat data is from the year preceding the asset sale. The market value of equity is for 6 days before the announcement date. : $\because$. subsamples at the $0.1,0.05$ and 0.01 levels respectively (in parentheses we report the significance level for the median test).

\begin{tabular}{|l|c|c|c|}
\hline Sample and sample size & $\begin{array}{c}\text { Whole sample } \\
93\end{array}$ & $\begin{array}{c}\text { Payout sample } \\
40\end{array}$ & $\begin{array}{c}\text { Re-invest sample } \\
53\end{array}$ \\
\hline Firm characteristic & $\begin{array}{c}\text { Mean } \\
\text { (Median) }\end{array}$ & $\begin{array}{c}\text { Mean } \\
\text { (Median) }\end{array}$ & $\begin{array}{c}\text { Mean } \\
\text { (Median) }\end{array}$ \\
\hline
\end{tabular}

Panel A. Asset sale characteristics.

\begin{tabular}{|c|c|c|c|}
\hline Value of sale (million \$) & $\begin{array}{l}120.68 \\
(32.50)\end{array}$ & $\begin{array}{l}129.64 \\
(50.50)\end{array}$ & $\begin{array}{l}114.00 \\
(22.00)\end{array}$ \\
\hline $\begin{array}{l}\text { Market value of equity } \\
\left.\text { (million } \$)()^{+\infty}\right)\end{array}$ & $\begin{array}{r}904.78 \\
(150.45) \\
\end{array}$ & $\begin{array}{r}740.30 \\
(110.00) \\
\end{array}$ & $\begin{array}{l}1028.92 \\
(292.64) \\
\end{array}$ \\
\hline $\begin{array}{l}\text { Value of sale/ value of } \\
\left.\text { equity }{ }^{-(* \infty)}\right)\end{array}$ & $\begin{array}{r}0.69 \\
(0.23) \\
\end{array}$ & $\begin{array}{c}1.32 \\
(0.42) \\
\end{array}$ & $\begin{array}{r}0.18 \\
(0.13) \\
\end{array}$ \\
\hline $\begin{array}{l}\text { Total assets (TA) } \\
\text { (million \$) }\end{array}$ & $\begin{array}{l}1470.48 \\
(348.93)\end{array}$ & $\begin{array}{l}1588.04 \\
(348.93)\end{array}$ & $\begin{array}{l}1387.21 \\
(366.05)\end{array}$ \\
\hline $\begin{array}{l}\text { Value of sale/TA } \\
\cdots(+\infty)\end{array}$ & $\begin{array}{c}0.11 \\
(0.09)\end{array}$ & $\begin{array}{c}0.17 \\
(0.13)\end{array}$ & $\begin{array}{c}0.07 \\
(0.06)\end{array}$ \\
\hline $\begin{array}{l}\text { Gain on sale/Market vat- } \\
\text { ue of equity }\left({ }^{\circ}\right)\end{array}$ & $\begin{array}{l}-0.95 \% \\
(0.19 \%)\end{array}$ & $\begin{array}{c}2.23 \% \\
(1.41 \%)\end{array}$ & $\begin{array}{l}-3.25 \% \\
(0.00 \%)\end{array}$ \\
\hline \multicolumn{4}{|c|}{ B. Leverage characteristics of selling firm. } \\
\hline Short-term liabilities/TA & $\begin{array}{c}0.32 \\
(0.29) \\
\end{array}$ & $\begin{array}{l}0.35 \\
(0.28) \\
\end{array}$ & $\begin{array}{c}0.30 \\
(0.29) \\
\end{array}$ \\
\hline Short-term debtrTA & $\begin{array}{r}0.09 \\
(0.05)\end{array}$ & $\begin{array}{c}0.11 \\
(0.07)\end{array}$ & $\begin{array}{c}0.07 \\
(0.04)\end{array}$ \\
\hline Long-term debtrTA * & $\begin{array}{r}0.27 \\
(0.21) \\
\end{array}$ & $\begin{array}{r}0.31 \\
(0.28) \\
\end{array}$ & $\begin{array}{r}0.23 \\
(0.20) \\
\end{array}$ \\
\hline $\begin{array}{l}\text { Long-term + short-term } \\
\text { debtrTA } *\left(^{*}\right)\end{array}$ & $\begin{array}{c}0.36 \\
(0.31) \\
\end{array}$ & $\begin{array}{c}0.42 \\
(0.34)\end{array}$ & $\begin{array}{c}0.30 \\
(0.23) \\
\end{array}$ \\
\hline
\end{tabular}




\begin{tabular}{|c|c|c|c|}
\hline Sample and sample size & $\begin{array}{c}\text { Whole sample } \\
.93 \\
\end{array}$ & $\begin{array}{c}\text { Payout sample } \\
40 \\
\end{array}$ & $\begin{array}{c}\text { Re-invest sample } \\
53\end{array}$ \\
\hline Firm characteristic & $\begin{array}{c}\text { Mean } \\
\text { (Median) }\end{array}$ & $\begin{array}{c}\text { Mean } \\
\text { (Median) }\end{array}$ & $\begin{array}{c}\text { Mean } \\
\text { (Median) }\end{array}$ \\
\hline \multicolumn{4}{|c|}{ C. Performance characteristicts of selling firm. } \\
\hline $\begin{array}{l}\text { Net incomerta } \\
\left.()^{\circ}\right)\end{array}$ & $\begin{array}{l}-0.01 \\
(0.01)\end{array}$ & $\begin{array}{c}-0.03 \\
(-0.02)\end{array}$ & $\begin{array}{c}0.00 \\
(0.01)\end{array}$ \\
\hline Operating income $\left./ T A()^{\circ}\right)$ & $\begin{array}{c}0.09 \\
(0.10)\end{array}$ & $\begin{array}{c}0.07 \\
(0.07)\end{array}$ & $\begin{array}{c}0.10 \\
(0.12)\end{array}$ \\
\hline $\begin{array}{l}\text { Interest coverage } \\
\text { (EBIT/hnterest payments) } \\
\text { (**) }\end{array}$ & $\begin{array}{l}16.11 \\
(2.54)\end{array}$ & $\begin{array}{c}0.98 \\
(1.56)\end{array}$ & $\begin{array}{l}27.04 \\
(3.38)\end{array}$ \\
\hline $\begin{array}{l}\text { Cumulative net of market } \\
\text { retums ( } 250 \text { days before } \\
\text { sale) }\left({ }^{-\infty}\right)\end{array}$ & $\begin{array}{c}-6.25 \% \\
(-10.97 \%)\end{array}$ & $\begin{array}{c}-8.60 \% \\
(-14.45 \%)\end{array}$ & $\begin{array}{l}-4.48 \% \\
(3.75 \%)\end{array}$ \\
\hline Tobin's q *(") & $\begin{array}{c}0.83 \\
(0.73)\end{array}$ & $\begin{array}{c}0.67 \\
(0.67)\end{array}$ & $\begin{array}{r}0.94 \\
(0.87 !\end{array}$ \\
\hline $\begin{array}{l}\text { Managerial ownership } \\
\text { (**) }\end{array}$ & $\begin{array}{c}0.13 \\
(0.08)\end{array}$ & $\begin{array}{c}0.17 \\
(0.12)\end{array}$ & $\begin{array}{c}0.11 \\
(0.05)\end{array}$ \\
\hline
\end{tabular}

1.56, indicating that for the typical firm eamings exceed interest payments by $56 \%$. In contrast, the median coverage ratio for the other firms exceeds 3 . Hence, the typical firm paying out the proceeds is close to being unable to pay interest out of eamings. This suggests that firms paying down debt may have a powerful motivation to sell assets, providing evidence consistent with the financing hypothesis.

For the whole sample, the average ratio of the sum of short-term and long-term debt to the book value of total assets, $\mathbf{0 . 3 1}$, is larger than the average ratio reported in Bemanke and Campbell (1988) for the 1986 universe of Compustat firms (0.28), providing some evidence that our sample firms have above-average leverage. Using the ratio of the book value of long-term debt to the book value of tolal assets, there is no difference between the firms that intend to pay 
out the proceeds and the others using the median test. There is atso no evidence that firms paying out the proceeds have significantly more shor-term debt or short-term liabilities. However, the ratio of short-term and long-term debt to total assets is significantly higher for firms that pay out the proceeds for the mean and the median.

The firms in the sample perform poorty before the sale. Their average net income is negative and their median net income is trivially small. Their cumulative net of market retum over the preceding year is negative. Finally, their Tobin's $q$ is low. Moreover, the performance of firms paying out the proceeds is significantly worse than the performance of the other firms at the 0.05 level when measured by net income to total assets. In addition, the firms that pay out proceeds typically lose money in the year before the sale. Cumulative net of market returns for the year prior to the sale are also lower for these firms at the 0.05 level. Finally, the firms in the payout sample have a significantly lower Tobin's q ratio indicating that the firms that retain the proceeds have better investment opportunities. For the firms in the re-invest sample, median net income divided by total assets is extremely small and median cumulative net of market retums are positive. Median $q$ is below one for these firms.

Though asset sales by firms in distress have been studied in a number of papers recently (Asquith, Gertner and Scharfstein (1991), Brown, James and Mooradian (1993) and Ofek (1994)). id is important to note that the firms in our sample were not selected because of distress or poor performance. Further, as explained eartier, we removed from the sample those firms that were bankrupt at the time of the asset sale announcement. Only one firm files a Chapter 11 petition in the year following the asset sale. Seven firms defaulted on their loans or restruclured their debt in the year before the sale; four of these firms paid down debt from the proceeds. Two firms renegotiated loans in the year before the sale and these two firms paid down debt with the proceeds. Two firms defaulted after the sale and both used the proceeds to pay down debt. 
Hence, the typical sale in our sample is not undertaken to cure a default or as part of a workout. The median firm is, however, a poor performer whose net income is just about zero and whose stock price is not keeping up with the market.

There is some weak evidence that being a takeover larget makes it more likely that a firm will pay out the proceeds of an asset sale. In the 12 months preceding the asset sale, there is evidence of takeover activity for $\mathbf{9}$ firms and $\mathbf{5}$ of these firms paid out the proceeds of the asset sale. Further, there is evidence of takeover activity for 5 firms following the sale and 3 of these paid out the proceeds.

One question of importance given our theoretical analysis is whether managers that sell assets and retain the proceeds have fewer incentives to maximize shareholder wealth. Table 1 reports average managerial ownership for the firms that retain the proceeds and for the ones that do not. Managerial ownership is significantly higher for firms that pay out the proceeds, so that agency problems may be smaller in these firms because it is more costly for management to pursue its objectives. Because of the difference in the market value of equity between firms that repay debt and those that do not, it turns out that, although managers own a larger fraction of shares in firms that repay debt, their dollar stake is smaller.

\section{Section 4. The stock-prlce reaction of asset sales.}

To measure stock-price reactions to asset sales, we estimate the market model from 250 to 50 days before the announcement. Table 2 reports the stock-price reactions for the full sample and also on the basis of the use of the proceeds. Our finding for the full sample of significantly positive cumulative retums $(1.41 \%)$ for days -1 and 0 is comparable to the findings in the earlier papers.

The stock-price reaction differs significantly between sales in the payout sample and saies 


\begin{tabular}{|c|c|c|c|c|}
\hline \multicolumn{5}{|c|}{$\begin{array}{l}\text { Table } 2 \\
\text { Average percentage stock-price reaction to the announcement of a slonificant } \\
\text { asset sale } \\
\text { The abnormal retums are market model prediction errors. Day } 0 \text { is the announcement } \\
\text { day. The sample comprises } 93 \text { asset sales obtained from inspection of } 8 \mathrm{~K} \text { forms. } \\
\text { denote, respectively, significance at the } 0.10,0.05 \text { and } 0.01 \text { levels using } 2 \text {-statistics. } \\
\text { The fraction of positive observations is in parentheses. } n \text { denotes sample size. }\end{array}$} \\
\hline $\begin{array}{l}\text { Days relative to } \\
\text { the event day }\end{array}$ & $\begin{array}{l}\text { Whole } \\
\text { sample } \\
n=93\end{array}$ & $\begin{array}{l}\text { Payout } \\
\text { sample } \\
n=36\end{array}$ & $\begin{array}{l}\text { Re-invest } \\
\text { sample } \\
n=51\end{array}$ & Difference \\
\hline-5 & $\begin{array}{r}0.58^{\circ} \\
(0.50) \\
\end{array}$ & $\begin{array}{r}0.71 \\
(0.50) \\
\end{array}$ & $\begin{array}{c}0.38 \\
(0.51) \\
\end{array}$ & 0.34 \\
\hline-4 & $\begin{array}{c}0.19 \\
(0.43) \\
\end{array}$ & $\begin{array}{c}0.83^{+0} \\
(0.40) \\
\end{array}$ & $\begin{array}{l}-0.30 \\
(0.45)\end{array}$ & $1.13^{* *}$ \\
\hline-3 & $\begin{array}{c}-0.18 \\
(0.53) \\
\end{array}$ & $\begin{array}{l}-0.52 \\
(0.50) \\
\end{array}$ & $\begin{array}{c}0.09 \\
(0.55) \\
\end{array}$ & -0.43 \\
\hline-2 & $\begin{array}{l}1.13^{* 0 *} \\
(0.63)\end{array}$ & $\begin{array}{c}0.69 \\
(0.60) \\
\end{array}$ & $\begin{array}{l}1.47^{* * *} \\
(0.68) \\
\end{array}$ & $-0.78^{\circ}$ \\
\hline-1 & $\begin{array}{c}0.17 \\
(0.42) \\
\end{array}$ & $\begin{array}{r}1.03^{\circ} \\
(0.45) \\
\end{array}$ & $\begin{array}{l}-0.48 \\
(0.40) \\
\end{array}$ & $1.51^{*}$ \\
\hline 0 & $\begin{array}{l}1.25 \\
(0.55) \\
\end{array}$ & $\begin{array}{l}2.89^{\circ * * 0} \\
(0.60)\end{array}$ & $\begin{array}{c}0.00 \\
(0.51) \\
\end{array}$ & $2.89 * *$ \\
\hline+1 & $\begin{array}{c}-0.11 \\
(0.48) \\
\end{array}$ & $\begin{array}{l}-0.40 \\
(0.45) \\
\end{array}$ & $\begin{array}{c}0.11 \\
(0.51) \\
\end{array}$ & -0.29 \\
\hline+2 & $\begin{array}{c}0.61 * 0 \\
(0.53) \\
\end{array}$ & $\begin{array}{r}0.82^{\circ} \\
(0.58) \\
\end{array}$ & $\begin{array}{c}0.45 \\
(0.49) \\
\end{array}$ & -0.37 \\
\hline+3 & $\begin{array}{l}-0.07 \\
(0.52) \\
\end{array}$ & $\begin{array}{r}0.02 \\
(0.55) \\
\end{array}$ & $\begin{array}{l}-0.13 \\
(0.49) \\
\end{array}$ & 0.15 \\
\hline+4 & $\begin{array}{l}-0.23 \\
(0.43) \\
\end{array}$ & $\begin{array}{c}-0.04 \\
(0.43) \\
\end{array}$ & $\begin{array}{l}-0.38 \\
(0.43) \\
\end{array}$ & 0.34 \\
\hline+5 & $\begin{array}{l}-0.45^{\circ} \\
(0.42)\end{array}$ & $\begin{array}{l}-0.31 \\
(0.45)\end{array}$ & $\begin{array}{l}-0.56 \\
(0.40)\end{array}$ & 0.25 \\
\hline
\end{tabular}


in the re-invest sample. Though those firms that pay out the proceeds experience a significant increase in value, the announcement of asset sales in the re-invest sample has fittle valuation effect on the firms in our sample, except on day -2 where there is a significant positive effect for these firms. To make sure that our conclusions are robust to taking into account this effect on day -2 , we later make sure that they also hold when we use cumulative retums for the period from day -5 to day +5 .

The significantly higher announcement effect for sales in the payout sample is consistent with the existence of significant agency costs of managerial discretion. However, the interpretation of the results of table 2 is rendered more difficult by the fact that firms in the payout sample typically have poorer performance than the firms in the re-invest sample. Hence, the result in table 2 might reflect that firms that perform poorly and sell assets have a positive stock-price reaction irrespective of the use of the proceeds. This would be the case if, for such firms, any asset sale reduces the costs of financial distress. In this case, the results of table 2 would not be supportive of the role of agency costs of managerial discretion for the use of the proceeds. To investigate this, table 3 provides mean and median cumulative abnormal retums for various subsamples of asset sales. This table confirms that the mean and median cumulative average abnormal retum for the payout sample are significantly higher than for the re-invest sample.

In all subsamples in table 3, the cumulative average retum is higher for the firms that have some prior evidence of poor performance or financial difficulties than for the other firms. However, for the traditional window of days -1 and 0 , the difference in cumulative average retums between the firms that have prior evidence of poor performance or financial difficulties and the other firms is never significant (except barely so at the 0.10 level for firms that have negative news in the WSJ). For the longer window of days -5 to +5 , the mean average abnormal return is significantly higher for firms whose WSJ announcement includes negative news, for firms with negative net 
Table 3

Cumulatlve percentage abnormal returns for the whole sample and varlous subsamples

The cumulative abnormal retums are obtained from market model residuals; 2-statistics are given in parentheses for the means, p-values for the sign-rank test are given in square brackets and p-values for the median test are given in curly brackets.

\begin{tabular}{|l|r|r|r|r|}
\hline & \multicolumn{2}{|c|}{ From day -1 to day 0 } & \multicolumn{2}{c|}{ From day -5 to day +5} \\
\hline & Mean & Median & Mean & Median \\
\hline $\begin{array}{l}\text { Whole sample } \\
\text { (Sample size; }\end{array}$ & 1.41 & 0.72 & 2.80 & 1.70 \\
$\begin{array}{l}\text { number that } \\
\text { pay out pro- } \\
\text { ceeds) }\end{array}$ & $(3.61)$ & {$[0.15]$} & $(2.80)$ & {$[0.02]$} \\
\hline
\end{tabular}

A. Asset sales in payout sample versus asset sales in re-invest sample.

\begin{tabular}{|l|c|r|r|r|}
\hline $\begin{array}{l}\text { Payout sample } \\
(40)\end{array}$ & $\begin{array}{c}3.92 \\
(5.93)\end{array}$ & $\begin{array}{c}1.90 \\
{[<0.01]}\end{array}$ & $\begin{array}{c}5.65 \\
(5.07)\end{array}$ & $\begin{array}{c}4.42 \\
{[<0.01]}\end{array}$ \\
\hline $\begin{array}{l}\text { Re-invest sam- } \\
\text { ple (53) }\end{array}$ & -0.48 & -0.34 & 0.65 & 0.25 \\
\hline Difference & $(0.43)$ & {$[0.50]$} & $(0.34)$ & {$[0.94]$} \\
& 4.40 & 2.24 & 5.00 & 4.17 \\
& $(4.21)$ & $\{0.03)$ & $(3.06)$ & $\{0.08\}$ \\
\hline
\end{tabular}

B. WSJ announcement includes negative news.

\begin{tabular}{|c|c|c|c|c|}
\hline $\begin{array}{l}\text { Includes } \\
(50 ; 27)\end{array}$ & $\begin{array}{c}2.31 \\
(3.61)\end{array}$ & $\begin{array}{c}1.01 \\
{[0.08]}\end{array}$ & $\begin{array}{c}5.07 \\
(4.10)\end{array}$ & $\begin{array}{c}4.00 \\
{[<0.01]}\end{array}$ \\
\hline $\begin{array}{l}\text { Does not } \\
\text { include }(43 ; 13)\end{array}$ & $\begin{array}{c}0.37 \\
(1.38)\end{array}$ & $\begin{array}{c}0.80 \\
{[0.95]}\end{array}$ & $\begin{array}{c}0.15 \\
(0.34)\end{array}$ & $\begin{array}{c}0.25 \\
{[0.83]}\end{array}$ \\
\hline Difference & $\begin{array}{l}12.94 \\
(1.67)\end{array}$ & $\begin{array}{c}0.21 \\
\{0.27\}\end{array}$ & $\begin{array}{c}4.92 \\
(2.78)\end{array}$ & $\begin{array}{r}3.75 \\
\{<0.01\}\end{array}$ \\
\hline \multicolumn{5}{|c|}{ C. Net income (year before the sale). } \\
\hline $\begin{array}{l}\text { Negative } \\
(37 ; 22)\end{array}$ & $\begin{array}{c}2.12 \\
(3.35) \\
\end{array}$ & $\begin{array}{c}0.85 \\
{[0.12]}\end{array}$ & $\begin{array}{c}4.38 \\
(3.41) \\
\end{array}$ & $\begin{array}{c}4.19 \\
{[0.05]} \\
\end{array}$ \\
\hline $\begin{array}{l}\text { Positive } \\
(45 ; 12)\end{array}$ & $\begin{array}{r}0.13 \\
(1.54) \\
\end{array}$ & $\begin{array}{l}-0.93 \\
{[0.96]} \\
\end{array}$ & $\begin{array}{c}1.27 \\
(0.60) \\
\end{array}$ & $\begin{array}{c}0.87 \\
{[0.26]} \\
\end{array}$ \\
\hline Difference & $\begin{array}{c}1.99 \\
(1.11)\end{array}$ & $\begin{array}{c}1.78 \\
0.27\}\end{array}$ & $\begin{array}{c}3.11 \\
(2.50)\end{array}$ & $\begin{array}{c}3.32 \\
\{0.12\}\end{array}$ \\
\hline
\end{tabular}




\begin{tabular}{|c|c|c|c|c|}
\hline & \multicolumn{2}{|c|}{ From day -1 to day 0} & \multicolumn{2}{|c|}{ From day -5 to day +5} \\
\hline & Mean & Median & Mean & Median \\
\hline $\begin{array}{l}\text { Negative } \\
(53 ; 26)\end{array}$ & $\begin{array}{c}2.15 \\
(3.38)\end{array}$ & $\begin{array}{c}0.35 \\
{[0.16]}\end{array}$ & $\begin{array}{c}5.42 \\
(3.67)\end{array}$ & $\begin{array}{r}3.81 \\
{[<0.01]}\end{array}$ \\
\hline $\begin{array}{l}\text { Positive } \\
(40 ; 14)\end{array}$ & $\begin{array}{c}0.43 \\
(1.58)\end{array}$ & $\begin{array}{c}0.89 \\
{[0.62]}\end{array}$ & $\begin{array}{l}-0.67 \\
(0.00)\end{array}$ & $\begin{array}{c}0.07 \\
{[0.85]}\end{array}$ \\
\hline Difference & $\begin{array}{c}1.72 \\
(1.51)\end{array}$ & $\begin{array}{l}-0.54 \\
\{0.61\}\end{array}$ & $\begin{array}{c}6.09 \\
(4.09)\end{array}$ & $\begin{array}{r}3.74 \\
\{<0.01\}\end{array}$ \\
\hline \multicolumn{5}{|c|}{ E. Coverage ratio (EBIT/Interest payments). } \\
\hline & \multicolumn{2}{|c|}{ From day -1 to day 0} & \multicolumn{2}{|c|}{ From day -10 to day +10} \\
\hline $\begin{array}{l}\text { Below median } \\
(42 ; 23)\end{array}$ & $\begin{array}{c}1.62 \\
(2.71)\end{array}$ & $\begin{array}{c}1.00 \\
{[0.20]}\end{array}$ & $\begin{array}{c}3.76 \\
{[2.46]}\end{array}$ & $\begin{array}{c}3.17 \\
{[0.04]}\end{array}$ \\
\hline $\begin{array}{l}\text { Above median } \\
(39 ; 11)\end{array}$ & $\begin{array}{l}0.40 \\
(2.08) \\
\end{array}$ & $\begin{array}{c}0.02 \\
{[0.90]}\end{array}$ & $\begin{array}{r}1.73 \\
{[1.47]} \\
\end{array}$ & $\begin{array}{c}0.87 \\
{[0.24]}\end{array}$ \\
\hline Difference & $\begin{array}{c}1.22 \\
(0.51)\end{array}$ & $\begin{array}{c}0.98 \\
\{0.32\}\end{array}$ & $\begin{array}{c}2.02 \\
{[0.75]}\end{array}$ & $\begin{array}{r}2.30 \\
\{0.15\}\end{array}$ \\
\hline
\end{tabular}

income for the year before the sale and for firms with negative cumulative net of market retums for the year before the sale. Firms with coverage ratios lower than the sample median have cumulative abnormal retums insignificantly different from firms with higher coverage ratios. There is therefore no clear indication from table 3 that the higher abnormal retums of firms paying out the proceeds are due to the fact that these firms have had greater difficulties or exhibit poorer performance than the other firms.

Table 3 shows that there is substantial overlap between the firms that pay out the proceeds and those that exhibit poor performance and/or financial difficulties. This overlap does not affect the intepretation of the results for the shorter window since there the only way to split 
the sample to obtain a significant difference between abnormal retums is to divide the sample according to the use of the proceeds. However, for the longer window, other ways of dividing the data yield significant differences in abnormal retums. To understand better the impact of firm performance and use of the proceeds on the stock-price reaction, we divide the sample into four mutually exclusive groups in table 4. We define as poor performers firms with negative net of market cumulative retums the previous year, negative net income over the previous year and/or a WSJ sales announcement that provides some evidence of difficulties, such as negative eamings. For the 11-day window, asset sales have a significant positive average stock-price reaction only for poorty performing firms in the payout sample. This stock-price reaction is significantly different from the other three subsamples. The same conclusion holds with the 2-day window, except that firms paying out the proceeds and not performing poorty have a positive significant stock-price reaction that is significantly lower than the poorty performing firms that pay out the proceeds. Given that there are only 7 firms that pay out the proceeds and are not performing poorty, such a result has to be interpreted with caution.

Poorty performing firms that retain the proceeds have insignificant abnormal returns on average. Hence, the positive abnormal retums in our sample are not driven by the financial health of firms but by the use of the proceeds. The firms in our sample that neither repay debt nor perform poorly experience insignificant abnormal retums. The results from our sample are inconsistent with the view that positive abnormal retums of asset sales result solely from management's decision to reallocate corporate resources towards better uses within the corporation. Instead, our evidence suggests that asset sales where the procoeds are paid out rather than used to increase liquid assets under managerial control increase shareholder wealth. This evidence supports the view that agency costs of managerial discretion affect the stock-price reaction to asset salos. 


\section{Table 4}

11-day percentage abnormal retums for subsamples of asset sales Troubled firms are firms that have negative cumulative retums for the previous 250 days, negative net income for the previous year and/or a Wall Street Joumal asset-sale announcement that provides some evidence of distress. For each cell, we report the mean, the median in parentheses, the z-statistic for the mean in square brackets and, in curty brackets, the number of observations and the fraction of observations with a positive value. The lower right-hand cell gives the mean difference between troubled firms that pay out the proceeds and healthy firms that do not.

\begin{tabular}{||l|c|c|c||}
\hline & $\begin{array}{c}\text { Troubled } \\
\text { fims }\end{array}$ & Healthy firms & Difference \\
\hline Pay out proceeds & $\begin{array}{c}6.16 \\
(4.65)\end{array}$ & $\begin{array}{c}3.22 \\
(1.39)\end{array}$ & $2.9 d$ \\
& {$[3.58]$} & {$[1.38]$} & {$[2.67]$} \\
& $\{33 ; 0.70\}$ & {$[7 ; 0.57]$} & \\
\hline Re-invest proceeds & 1.16 & -0.44 & 1.60 \\
& $(1.15)$ & $(0.21)$ & {$[1.00]$} \\
& {$[0.80]$} & {$[0.60]$} & \\
\hline Difference & $\{36 ; 0.53\}$ & {$[17 ; 0.53\}$} & 6.60 \\
& 5.00 & 3.66 & {$[3.26]$} \\
\hline
\end{tabular}

A concem with table 4 is that the sample of poorly performing firms in the payout sample might be dominated by firms that are facing immediate financial difficulties, so that the positive average abnomal retum reflects the ability of these firms to sell assets successfully and hence reduce their financial difficulties. To investigate this possibility, we divided the sample into firms with a coverage ratio (EBIT divided by interest payments) above the sample median and firms with a coverage ratio below the sample median. We then compared stock-price reactions for firms with a coverage ratio below the sample median in the payout sample and those in the re-invest sample. We found that the 18 asset sales by firms with below-median coverage ratios in the reinvest sample have an insignificant abnormal retum that is significantly lower than the stock-price 
reaction for firms with below-median coverage ratios in the payout sample. Since the abnormal retums for firms that pay out the proceeds do not differ between firms with above and belowmedian coverage ratios, it is unlikely that the relation between abnormal retums and the use of the proceeds depends on the selling firm's financial situation.

In table 5, we provide results for additional subsamples of interest. First, we show the average and median abnormal retums for the sale announcements where the source for the use of the proceeds is similar to the source for the announcement. This sample comprises sales where the announcement is in the Dow-Jones wire or the WSJ with a WSJ story that has the use of the proceeds and where the announcernent date is the agreement date from the 8K filing with the use of the proceeds described in the $8 \mathrm{~K}$. These 16 observations have slightly higher mean and median retums than the 40 observations, but the z-statistic is lower and the p-value of the sign-rank test is higher for the 16 observations than for the 40 observations, possibly because of the smaller number of observations. Second, we show that, among the firms that do not pay out the proceeds, there is no evidence that there are subsamples of sales with average or median abnormal retums comparable to those of firms that pay out the proceeds when one focuses on the shorter window. For the longer window, there is no case where the z-statistic is significant when the firm does not pay out the proceeds, but the magnitude of the abnormal retums is faitly high in the case of the firms that sell an unprofitable division and retain the proceeds. In contrast, fims that sell assets to focus more on core operations but do not pay out the proceeds have very smail abnormal retums in absolute value and for the short windows both average and median abnormal retums are negative. 


\section{Table 5}

Percentage cumulative abnormal returns for additional subsamples Cumulative abnormal retums are obtained from market residuals for a sample of 93 large asset sales obtained from 8K forms from 1884 to 1989. The subsamples are constructed using information from press articles, the $8 \mathrm{~K}$ form, the annual report and the S\&P Standard Stock Reports. The simuttaneous announcement sample is the sample where the same source provides the announcement of the sale and of the use of the proceeds.

\begin{tabular}{|c|c|c|c|c|}
\hline \multirow[b]{2}{*}{$\begin{array}{l}\text { Subsamples de- } \\
\text { fined according } \\
\text { to use of pro- } \\
\text { ceeds and sale } \\
\text { motivation }\end{array}$} & \multicolumn{2}{|c|}{ From day -1 to day 0} & \multicolumn{2}{|c|}{ From day -5 to day +5} \\
\hline & $\begin{array}{c}\text { Mean } \\
\text { (Z-statistic) }\end{array}$ & $\begin{array}{l}\text { Median } \\
\text { [p-value for } \\
\text { sign-rank } \\
\text { test] }\end{array}$ & $\begin{array}{c}\text { Mean } \\
\text { (Z-statistic) }\end{array}$ & $\begin{array}{l}\text { Median } \\
\text { [p-value for } \\
\text { sign-rank } \\
\text { test] }\end{array}$ \\
\hline $\begin{array}{l}\text { Payout sample } \\
\text { (40) }\end{array}$ & $\begin{array}{c}3.92 \\
(5.93) \\
\end{array}$ & $\begin{array}{r}1.90 \\
\{<0.01\}\end{array}$ & $\begin{array}{r}5.65 \\
(5.07) \\
\end{array}$ & $\begin{array}{r}4.42 \\
{[<0.01]}\end{array}$ \\
\hline $\begin{array}{l}\text { Re-invest sam- } \\
\text { ple; simulta- } \\
\text { neous announ- } \\
\text { cement (16) }\end{array}$ & $\begin{array}{c}4.98 \\
(3.93)\end{array}$ & $\begin{array}{c}2.13 \\
{[0.19]}\end{array}$ & $\begin{array}{c}7.76 \\
(3.25)\end{array}$ & $\begin{array}{c}6.86 \\
{[0.04]}\end{array}$ \\
\hline $\begin{array}{l}\text { Focus on core; } \\
\text { re-invest sample } \\
\text { (21) }\end{array}$ & $\begin{array}{c}-0.46 \\
(-0.61)\end{array}$ & $\begin{array}{l}-0.34 \\
{[0.60]}\end{array}$ & $\begin{array}{c}0.50 \\
(0.82)\end{array}$ & $\begin{array}{l}-0.56 \\
{[0.93]}\end{array}$ \\
\hline $\begin{array}{l}\text { Sell unprofitable } \\
\text { division; re-in- } \\
\text { vest sample (14) }\end{array}$ & $\begin{array}{c}-1.41^{\circ} \\
(-0.31)\end{array}$ & $\begin{array}{l}-0.42 \\
{[0.43]}\end{array}$ & $\begin{array}{c}3.88 \\
(1.36)\end{array}$ & $\begin{array}{c}4.05 \\
{[0.07]}\end{array}$ \\
\hline $\begin{array}{l}\text { Finance acquisi- } \\
\text { tions or expan- } \\
\text { sions; r } \theta \text {-invest } \\
\text { sample (9) }\end{array}$ & $\begin{array}{r}1.24 \\
(1.44)\end{array}$ & $\begin{array}{c}1.03 \\
{[0.43]}\end{array}$ & $\begin{array}{c}0.47 \\
(0.01)\end{array}$ & $\begin{array}{c}0.25 \\
{[0.50]}\end{array}$ \\
\hline
\end{tabular}

Section 5. Explaining the cross-sectional variation in cumulative returns.

5.1. Relative proceeds and stock-price reaction.

The efficient deployment view of asset sales does not distinguish between poorly performing firms paying out asset sales proceeds and other firms selling assets. Since we 
document in this paper a sharp difference in the stock-price reaction between these firms, can our evidence be reconciled with the efficient deployment view? Our evidence in table 1 shows that firms paying out the proceeds have a signiticantly greater ratio of asset sale proceeds to the market value of their equity. Hence, if the seller's gain from selling an asset, i.e., the premium the bidder pays for the asset in excess of the asset's value when used by the seller, expressed as a percentage of the proceeds, is the same irrespective of the firm that sells the asset, one would expect a larger stock-price reaction for firms that pay out the proceeds. This argument suggests that the distinction we find could be due to the size of the proceeds relative to equity. However, as evidenced by regressions 1 and 2 of table 6, there is a significant relation between the stockprice reaction and the proceeds divided by the market value of equity, but this relation does not explain the higher average abnormal retum of the payout sample. "Regression 1 is consistent with the argument of Shleifer and Vishny (1992) that, given the illiquidity of the market for asset sales, large asset sales are more likely to fail. This is because, in this case, their success is better news than the success of small asset sales.

The literature on security issues generally emphasizes that they convey information to markets about the value of the issuing firm's securities or its assels; to the extent that asset sales are altematives to security issues, they could also reveal information about the value of the firm's securities or assets. This does not seem to be the case in our sample, though. This is because, if outsiders leam about the firm's demand for funds through the asset sale, a greater demand for funds would be bad news and the abnomal retum would be negatively related to the size of the asset sale. It is interesting to note that the positive relation between abnormal retums and the size of the proceeds is the opposite of that obtained in the literature on equity issues, since in that

\footnotetext{
- All regressions of table 6 are estimated using weighted least squares, where the weight is the reciprocal of the standard deviation of the residual of the market model regression.
} 


\begin{tabular}{|c|c|c|c|c|c|c|}
\hline \multicolumn{7}{|c|}{$\begin{array}{l}\text { Table } 6 \\
\text { Weighted least squares regresslons of the abnormai return on } \\
\text { firm and sale characteristlcs } \\
\text { The sales are obtained from inspection of } 8 \mathrm{~K} \text { forms. Managerial ownership is obtained from } \\
\text { proxy statements. The accounting loss is from the } 8 \mathrm{~K} \text { form. All other data is obtained from } \\
\text { Compustat and CRSP tapes. The Compustat data are from the year preceding the asset } \\
\text { sale. (t-statistics in parentheses below the coefficient estimates.) }\end{array}$} \\
\hline $\begin{array}{l}\text { Regression \#l } \\
\text { sample size } \\
\text { (event window) }\end{array}$ & $\begin{array}{l}1 / 81 \\
(-1,0)\end{array}$ & $\begin{array}{c}2 / 81 \\
(-5,+5)\end{array}$ & $\begin{array}{l}3 / 82 \\
(-1,0)\end{array}$ & $\begin{array}{c}4 / 82 \\
(-5,+5)\end{array}$ & $\begin{array}{l}5 / 79 \\
(-1,0)\end{array}$ & $\begin{array}{c}6 / 79 \\
(-5,+5)\end{array}$ \\
\hline Intercept & $\begin{array}{c}-0.37 \\
(-0.44)\end{array}$ & $\begin{array}{c}0.21 \\
(0.16) \\
\end{array}$ & $\begin{array}{c}-0.49 \\
(-0.43)\end{array}$ & $\begin{array}{c}0.77 \\
(0.46)\end{array}$ & $\begin{array}{c}0.31 \\
(0.21)\end{array}$ & $\begin{array}{c}1.95 \\
(0.89)\end{array}$ \\
\hline $\begin{array}{l}\text { Pay out proceeds } \\
\text { dummy }\end{array}$ & $\begin{array}{c}2.92 \\
(2.11)\end{array}$ & $\begin{array}{c}4.01 \\
(1.87)\end{array}$ & $\begin{array}{c}2.82 \\
(2.25)\end{array}$ & $\begin{array}{l}3.85 \\
(2.05)\end{array}$ & $\begin{array}{l}3.00 \\
(2.24)\end{array}$ & $\begin{array}{l}2.88 \\
(1.46)\end{array}$ \\
\hline Procoeds/Equity & $\begin{array}{c}1.22 \\
(2.54) \\
\end{array}$ & $\begin{array}{r}1.38 \\
(1.86) \\
\end{array}$ & & & & \\
\hline $\begin{array}{l}\text { Managerial owner- } \\
\text { ship }\end{array}$ & & & & & $\begin{array}{l}-2.54 \\
(-0.59)\end{array}$ & $\begin{array}{l}7.27 \\
(1.15)\end{array}$ \\
\hline Net income & & & $\begin{array}{c}0.05 \\
(0.01)\end{array}$ & $\begin{array}{l}-2.65 \\
(-0.20)\end{array}$ & & \\
\hline Tobin's q & & & & & $\begin{array}{c}-0.23 \\
(-0.16)\end{array}$ & $\begin{array}{l}-2.28 \\
(-1.10)\end{array}$ \\
\hline $\begin{array}{l}\text { Net of market cu- } \\
\text { mulative retums }\end{array}$ & & & $\begin{array}{l}-1.46 \\
(-0.79)\end{array}$ & $\begin{array}{l}-9.35 \\
(-3.38)\end{array}$ & $\begin{array}{l}-1.82 \\
(-0.93)\end{array}$ & $\begin{array}{l}-7.67 \\
(-2.66)\end{array}$ \\
\hline $\begin{array}{l}\text { Long-term } \\
\text { debvTotal assets }\end{array}$ & & & $\begin{array}{c}1.61 \\
(0.42) \\
\end{array}$ & $\begin{array}{c}-1.29 \\
(-0.23)\end{array}$ & & \\
\hline Adjusted $R^{2}$ & 0.14 & 0.09 & 0.04 & 0.15 & 0.04 & 0.15 \\
\hline $\begin{array}{l}\text { p-value for } \\
\text { F-test }\end{array}$ & $<0.01$ & 0.01 & 0.14 & $<0.01$ & 0.16 & $<0.01$ \\
\hline
\end{tabular}


literature some researchers find that the stock price decrease is increasing in the size of the issue.

\subsection{Abnormal returns and performance: A multivariate perspectlve.}

We investigated in section 4 the extent to which the difference in abnormal returns can be explained by the fact that a successful asset sale is more important for the firms that pay out the proceeds because these firms are in a poor financial situation and would face significant costs of financial distress without the succossful sale. In that section, dividing the sample according to recent performance or the extent of financial difficulties does not lead to significant differences between subsamples for the shorter event window, but does so for the longer event window. It could be that our classification of firms as poorly performing or better performing firms does not capture a relation between performance and stock-price reactions that could be captured by regressing stock-price reactions on levels of performance measures. To investigate this, we relate abnormal retums to net income, net of market stock retums for the past 250 days and the debtasset ratio in regressions 3 and 4.

The regression estimates in table 5 confirm the earlier results that the higher abnormal retum of firms using asset sale proceeds to repay debt cannot be explained by these firms having poorer performance or a more precarious financial situation. Whereas past stock retums are correlated with abnormal retums for the longer window, this effect does not explain why firms that repay debt have higher abnormal retums since the dummy variable that takes value one for the firms that pay out the proceeds is significant for both windows. Further, regressing abnormal retums on past performance could lead to significant results when abnormal retums are estimated

\footnotetext{
5 See Korajczyk, Lucas and McDonald (1990) for a review of the evidence on the determinants of the stock-price reaction to equity issues.
} 
from market residuals because the intercept of the market model estimates depends on past performance.

Regressions 5 and 6 relate abnormal retums to net-of-market cumulative retums for the past 250 days, Tobin's $q$ and managerial ownership. The financing hypothesis implies that there should be a negative relation between the stock-price reaction and the degree of agency costs. We would expect abnormal retums to be higher for firms with higher managerial ownership (provided that management is not using its control of voting rights for entrenchment purposes). One would expect high q firms to have lower agency costs of managerial discretion, so that the stock market would discount sales proceeds less for these firms. For the shorter window, these variables have no explanatory power whatsoever. For the longer window, these variables make the dummy variable for the use of the proceeds insignificant. This is because they are correlated with the use of the proceeds. In a logistic regression not reported here, we find that firms with low managenal ownership or high q are significantly more likely to retain the proceeds, so that introducing these variables in the regression makes it more difficult to estimate the coefficient on the use of the proceeds precisely.

\section{Section 6. Concluding remarks.}

In this paper, we have shown that for a sample of large asset sales the stock-price reaction is significantly positive only for those firms that plan to pay out the proceeds to claimholders. This evidence is inconsistent with the hypothesis that the market reacts favorably to asset sales simply because they lead to more efficient use of assets and the selling firm captures some of the benefit from the increased efficiency.

Our evidence is consistent with what we call the financing hypothesis. With this hypothesis, management sells assets to obtain funds to pursue its objectives when altemative 
funding is either too expensive given its objectives or unavailable. On average, firms benefit from announcing successful sales because a successful sale means that the firm received enough money to make the sale worthwhile. Further, proceeds are discounted when retained by the selling firm because of agency costs of managenal discretion. In our sample, firms selling assets typically are poor performers and they are more likely to pay out the proceeds when they find it difficult to service their debt. The average stock-price reaction to asset sales is positive and it is significantly higher for firms that pay out the proceeds. We do not, however, find a direct link between abnormal retums and proxies for agency costs of managerial discretion.

This paper raises some questions which should be addressed in further research. We do not explore why managers might be reluctant to sell assets. Is it that managers do not want to acknowledge failure or is it that complex organizations cannot change easily because of intra-firm relationships and quid pro quos? Though we are convinced that our evidence demonstrates the relevance of the financing hypothesis, it is also clear from our analysis and from our empirical results that the information conveyed by asset sales is difficult to evaluate because asset sales convey news about the value of the asset sold, the intended use of the proceeds and, possibly, the firm's financial health. Larger samples of possibly less significant asset sales might offer a way to disentangle these various effects with more precision and provide useful information on the relative importance of the financing hypothesis and of the efficient deployment hypothesis. In our analysis, we have not distinguished between payouts to shareholders and to debtholders. The market for corporate control could force managers to sell assets for which they do not have a comparative advantage and to pay out the proceeds to shareholders. Further research should therefore investigate the extent to which asset sales are the result of pressures from the market for corporate control.

In conclusion, our sample suggests that the efficient deployment hypothesis is not as 
useful as prior studies might have suggested. Perhaps one could view our evidence as showing that firms seem more aware of their comparative advantage when they are short of funds than otherwise. If this is the case, though, it provides further support for the view that the agency costs of managerial discretion matter and that debt plays a useful role in disciplining management."

- See Jensen (1988) and Stulz (1991). 


\section{References}

Alexander, G.J., Benson, P.G., and J.K. Kampmeyer, 1984, Investigating the valuation effects of announcements of voluntary corporate selloffs, Joumal of Finance 39, 503-517.

Asquith, P., R. Gertner and D. Scharfstein, 1991, An anatomy of financial distress: An examination of junk-bond issuers, NBER Working Paper No. 3942, NBER, Cambridge, MA.

Brown, D.T., C.M. James, and R.M. Mooradian, 1993, Asset sales by financially distressed firms, unpublished.

Bemanke, B., and J.Y. Campbell, 1988, is there a corporate debt crisis?, Brookings Papers on Economic Activity, 83-125.

Boot, A., 1992, Why hang on to losers? Divestitures and takeovers, Joumal of Finance 47, 14011424.

Easterbrook, F. H., 1984, Two-agency cost explanations of dividends, American Economic Review $74,650-659$.

Hart, O. and J. Moore, 1990, A theory of corporate financial structure based on the seniority of claims, MIT working paper No. 560.

Hite, G.L., J.E. Owers, and R.C. Rogers, 1987, The market for interfirm asset sales: Partial selfoffs and total liquidations, Joumal of Financial Economics 18, 229-252.

Jain, P., 1985, The effect of voluntary sell-off announcements on shareholder wealth, Joumal of Finance 40, 209-224.

Jensen, M.C., 1988, Agency costs of free cash how, corporate finance, and the market for takeovers, American Economic Review 76, 323-329.

Korajczyk, R.A., D. Lucas, and R.L. McDonaid, 1990, Understanding stock price behavior around the time of equity issues, in R. G. Hubbard, ed., Asymmetric information, corporate finance, and investment, The University of Chicago Press, Chicago, Illinois.

Lang, L., R.M. Stuk, and R.W. Walkling, 1989, Managerial performance, Tobin's $q$ and the gains from successful takeovers, Joumal of Finance 44, 771-789.

Lehn, K., and A. Poulsen, 1989, Free cash flow and stockholder gains in going private transactions, Journal of Finance 44, 771-789.

Mayers, D., and V. Singh, 1993, Divestiture program announcements: Wealth effects, redistributions and the structure of corporate debt, unpublished paper, The Ohio State University.

McConnell, J.J. and C. Muscarella, 1985, Corporate capital expenditures decisions and the 
market value of the firm, Joumal of Financial Economics 14, 399-422.

Miller, M., and K. Rock, 1985, Dividend policy under asymmetric information, Joumal of Finance 40. $1031-1051$.

Myers, S.C., 1977, The determinants of corporate borrowing, Joumal of Financial Economics 5, 147-175.

Myers, S.C., and N.S. Majluf, 1984, Corporate financing and investment decisions when firms have information that investors do not have, Joumal of Financial Economics 13, 187-221.

Ofek, E., 1994, Capital structure and firm response to poor performance: An empirical analysis. Joumal of Financial Economics 34, 3-31.

Shleifer, A. and R. Vishny, 1992, Liquidation values and debt capacity: A market equilibrium approach, Joumal of Finance 47, 1343-1366.

Stulz, R.M., 1990, Managerial discretion and optimal financing policies, Joumal of Financial Economics 26, 3-28.

Weisbach, M.S., 1993, The CEO and the firm's investment decision, unpublished working paper, University of Rochester, NY. 


\section{Appendix: Brief Description of Asset Sales}

The following material briefly describes the asset sales in our sample. Each sale was reported to the SEC in an $8 \mathrm{~K}$ filing, indicating that the sale represented a "significant amount of assets." Information regarding each sale is gathered from several sources, including Annual Reports, 8Ks, the Wall Street Joumal, Dow Jones News Service, S\&P Standard Stock Reports, and other news sources.

The source of the date of the first public announcement of the asset sale is indicated below in parentheses following the announcement date; DW indicates that the announcement was in the WSJ (we used one trading day before WSJ story as the announcement date), DJ indicates that the story was reported over the Dow Jones News Wire but was not reported in the WSJ on the same or following date, Agreement date indicates that the first public date related to the announcement was the date the sale agreement was signed, as reported in the $8 K$.

Format of Asset Sale Information:

Seller / Buyer

Cumulative Abnormal Return $(-1,+1)$ in percent / Announcement Date (Source of Announcement Date)

Price (in miltions) / Gain on Sale (in millions)

Business of Asset Sold / Business of Buyer

Use of Funds from Sale / Code [0-strategic. 1=cash paid out of firm through debt reduction and/or stock repurchase] / Source of information on use of funds.

Brief Detaik (including information on payouts to stockhoiders through repurchases where applicable).

Adobe Resources Corp / Equitable Resources

$7.06 / 861230$ (D.)

$\$ 22.4$ / NA

Oil Wells \& Land / Natural Gas

Reduce Debt / 1 / Annual Report

Adobe Resources had a loss in the quarter around the sale due to lower oil prices. The asset sale occurred at the same time the firm called $\mathbf{5 5}$ milion in convertible debentures and enabled Adobe Resources to reduce its long-term debt to zero. The firm mentioned that the assets were not consistent with their longrange objectives. Stock repurchase: On 860128 , bought back a million shares for $\$ 12$ million and may buyback 500,000 more. No indication of connection to asset sale.

Airgas Inc. / Jackson Acquisition Company

$7.25 / 890912$ (DJ)

$\$ 70 / \$ 32.2$

Manufacturing / NA

Reduce Debt / 1 / 8K

Airgas went public in 1986 and made several acquisitions over the following two years. This asset sale enabled the firm to reduce borrowings under a revolving credit facility by $\$ 50$ million and was consistent with their long-term plan to emphasize gas distribution. 
Alied Signal Inc. (two sales) / (1) Lanesborough Corp (2) Commerzbank AG

(1) -3.59 (2) $4.77 /$ (1) 870406 (DW) (2) 870325 (DJ)

(1) $\$ 479$ (2) NA / All discontinued operations gave $\$ 79$ million gain.

(1) Electronics (2) Electronics / (1) NA (2) NA

(1) \& (2) Reduce debt, share buyback and investment in core businesses / (1) \& (2) $1 /$ (1) \& (2) Annual Report

Allied Signal was formed by the merger of Signal Cos. and Allied Corp in 1985. These asset sales are part of program to reduce debt and concentrate the new firm's assets in desired areas. Stock repurchases: firm announced that proceeds from asset sales would be used to buyback shares but no additional information on number or price of shares available.

American Bamick Resources / Peabody Coal Company

-3.41/ 870331 (Agreement date)

$\$ 12.5 / \mathrm{NA}$

Coal operations / Mining

Not profitable / O / 8K

Over the previous 5 years, this successful firm had grown into one of the largest North American gold producers, in part through acquisitions. This sale was its exit from unprofitable coal operations.

American Brands / MacAndrews and Forbes Holdings Inc

$2.19 / 860725$ (Agreement date)

$\$ 14 /$ NA

Cigar Co. / NA

Strategic / $0 /$ Annual Report

Faced with poor performance in the tobacco market, American Brands was engaged in a program of diversification and intemational expansion. The firm sold this tobacco unit as part of this plan.

Amfac Inc. / Borden Inc. Bnd Rabin Brothers

$-2.14 / 861112$ (DW)

NA / $\$ 20$

Fisher Cheese Co. I Diversified food companies

Strategic / $0 / 8 \mathrm{~K}$

Amfac sold Fisher Cheese Co in an effort to streamline operations and strengthen its financial position.

Armco Inc. / Kawasaki Steel

1.02 / 890324 (Agreement date)

$\$ 350 / \$ 109.4$

Steel Division / Steel

Joint Venture / 0 / WS.J. 8K

Kawasak Steel (which had a $40 \%$ stake in the sold unit) purchased remaining interest as part of a joint venture with Armco. 
Artra Group Inc. I WWR Corp.

$8.11 / 890808$ (DJ)

$\$ 25.5 /-\$ 16.5$

Laboratory Supply / Photo Supplies

Reduce debt, paydown bank loans / 1 / Annual Report

The firm sold several unprofitable assets that it had proviously purchased as part of an expansion plan.

Baker Hughes Inc / Oy Tampella AB

$-2.25 / 890313(\mathrm{DW})$

$\$ 130 / \$ 0$

Mining Equipment / NA

Strategic / O / Annual Report

Baker Hughes was formed in 1987 as merger of Baker International and Hughes Tool Co. The sold division did not fit in with the long-run plans of the new company.

Ball Corporation / TBG Europe

$-5.05 / 870129$ (DW)

$580 / 58$

Glass and Container Manufacturing / Joint Venture

Joint Venture 10 / WSJ, BK

The asset sale was a spinoff of Ball's glass container business into a $50-50$ joint venture with a European firm.

Banner Industries / Diamond Monitors

$-1.58 / 870331$ (DW)

NA / NA

Gas Detection Device Manufacturing / NA

Restructuring to divest operations not meeting growth and profit objectives $10 / 8 \mathrm{~K}$

In early 1987 the firm purchased Rexnord and this sale was part of a program to divest units not meeting the firm's growth and profit objectives.

R. G. Barry Corp / Jumping-Jack Shoes

$2.08 / 850923$ (DJ)

$\$ 2.3 /-\$ 1$

Footwear division / Footwear

Restructuring (strategic) / 0 / Annual report

This asset sale is the last of a series of sales to downsize the firm and turn profits positive. Stock repurchase: Firm agreed in November 1984 to buy about $10 \%$ of its shares from the Streim family for about $\$ 2.3$ million. 
Brown Group Inc / Jepson Corporation

$-0.98 / 850507$ (DW)

$\$ 50 /-\$ 9.3$

Recreational Products / NA

Strategic / 0 / Annual report

This asset sale completed Brown Group's strategic withdrawal from the volatile, low-return recreational products business.

\section{Canal Capital Corp / USK Acquisition Corporation}

$-3.37 / 880623(\mathrm{DJ})$

$\$ 6.875 / \$ 2$

Stockyard Business / NA (former insider)

Not profitable $10 /$ Annual report

The sale of its stockyard operations reflected the fundamental change in the nature of this firm's business from a stockyard firm to a diversified firm including real estate development, trading securities and Investing in ancient art.

Champion Intemational Corp / Stone Container

$-5.52 / 850930$ (DW)

$\$ 372.9 / \$ 0$

Paperboard milss, corrugated container and bag packaging plants / Paperboard packaging products Reduce Debt / 1 / WSJ

This sale was part of Champion Intemational's restructuring by selling assets to reduce debt incurred when it acquired St. Regis as a white knight.

Craig Corp / Bercor Inc

-0.05/ 851227 (Agreement date)

$\$ 1.61 / \$ 0$

Consumer electronics I NA

Cash for acquisitions $/ 0 /$ News reports, Annual report

Craig Corp sold essets of its consumer electronics division while at the same time it was developing an aggressive expansion policy that could lead to increased debt. Craig was retained as a consultant by the buyer. Stock repurchases: In October 1985, directors authorized repurchase of about \$1 million shares. No evidence that it was carried out. 
Crompton and Knowles (two sales) / (1) NCH Corp \& others (2) Univar Corp

(1) -0.23 (2) $-2.14 /$ (1) 881219 (Aoreement date) (2) 881205 (Aoreement date)

(1) $\$ 14.7$ (2) $\$ 11 /(1)-\$ .92(2)-\$ .8$

(1) Cleaning subsidiary (2) Chemicals / (1) Chemicals (2) Chemicals

(1) Strategic / 0 / Annual report; (2) Cash for acquisitions (strategic) / 0 / Annual report

These asset sales combined with acquisitions were part of management's strategy for improving long-term growth. Stock repurchases: In December 1986, redeemed all of preferred shares in private transaction for about $\$ 4.5$ million. In October 1986, bought back $8 \%$ of common shares from largest holder. Amount paid not disclosed.

\section{Crown Central Petroleum / Amoco Corp}

$-1.97 / 871112$ (Agreement date)

$\$ 166 / \$ 62.7$

Oil and gas exploration / Oil and gas

Reduce debt / 1 / 8K

The company suffered from falling oil prices and sold this asset to reduce debt and to concentrate on marketing and convenience stores instead of production.

\section{Culbro Corp / American Maize Products}

$11.74 / 851231$ (DW)

$585 /$ NA

Tobacco / NA

Strategic (also paid dividend of \$45 million) / $1 / 8 \mathrm{~K}$

As part of its plan to reduce reliance on tobacco industry. Culbro sold its smokeless tobacco division and distributed the proceeds to shareholders as a special dividend.

Di Giorgio / Bergen Brunswig Drug Co.

$0.00 / 860529(\mathrm{DN})$

$\$ 45 / \$ 6.2$

Drug division / Drug distribution

Reduce short-term debt / 1 / Annual report

To strengthen their balance sheet to support future growth, the firm took several actions to reduce debt including the sale of this asset and the conversion of debt to equity.

Divi Hotels NV / Palmer Group

$5.32 / 890824$ (DW)

S62 / NA

Hotels / Real estate and hotels

Obtain cash for working capital and to pay down debt / 1 / WS J

The firm sold several hotels after failing to obtain needed working capital in other ways. 
Ducommun Inc / Arrow Electronics Inc

$12.68 / 870921$ (OW)

$\$ 124 / \$ 10.5$

Electronics distribution / Electronic components

Reduce debt (Arrow Electronics traded $\$ 10$ million of Ducommun's debt held by Arrow for the esset, paid $\$ 79$ miltion cash used to reduce bank debt, and the rest made up In Arrow stock distributed to Ducommon shareholders.) / $1 /$ WSJ

Arrow Electronics paid $\$ 10$ million in Ducommon debt, $\$ 79$ million in cash and about $\$ 35$ million worth of Arrow stock for this asset. Ducommon used the proceeds to lower its outstanding debt. The firm's performance had suffered due to slowdown in the semiconductor and space Industries.

EAC Industries / Chromalloy Compressor Technologies

$9.04 / 881223$ (D)

$\$ 11.5 /-\$ 1.3$

Jet and Tank components manufacturing / NA

Reduce debt and focus on core hardware and related business / 1 / BK

This firm had several unprofitable years and sold this asset (and several others) to reduce debt and concentrate on its core. In addition a group held a more than $10 \%$ stake in the firm.

Electrosound Group Inc (two sales) / (1) Audio Sub Inc (2) Mitsubishi

(1) -7.51 (2) $-6.08 /(1) 890310$ (DJ) (2) 890626 (DW)

(1) $\$ 2.5$ (2) $\$ 1.5 /(1) \$ .418$ (2) NA

(1) Commercial Duplicating (2) Compact Disk Manufacturing / (1) NA (2) Manufacturing

(1) Strategic (2) Strategic / (1) 0 (2) $0 /$ (1) Annual report (2) Annual report

The firm sold its commerical dupliceting operation and ended a joint venture with Mitsubishi because they were unprofitabie. This enabled them to concentrate on core businesses and reduce debt. Stock repurchase: In June 1988. Electrosound repurchased \$1,080,000 worth of shares from Cinram Lid. No evidence of connection to asset sale.

Emviropact Inc / GSX Tank Management

$11.83 / 891023$ (D)

$\$ 5.4 / \$ 1.4$

Pump drlling division / NA

Reduce debt, pay taxes and increase working capital / 1 / Annual report

The firm sold these operations in mid-1989 to reduce debt and retum to profitability.

Equitec Financial Group Inc / Hallwood Group Inc.

$3.69 / 891018$ (D)

$\$ 76.2 / N A$

Real Estate Investment Partnershlps / Real Estate

Financial difficulties, need cash / 1 / Annual report

This financial servlce firm was hard hit by the Tax Reform Act of 1986 and sold assets as part of an attempt to avoid bankruptcy. 
Federal Mogul / CMV Interamerica Inc $1.80 / 890109$ (DW)

$\mathrm{NA} / \mathrm{SB.3}$

Dlamond blade manufacturing / Blade manufacturing

Used part of proceeds to repurchase one milition common shares and to create an ESOP as a defensive tactic against possible bidder Nortek Inc. $/ 1$ / WSJ

This firm, in response to a threatened hostile takeover, refocused the firm on its core businesses by selling this division. It used part of the proceeds to repurchase 1 milion shares and create an ESOP. Stock repurchases: The announced defensive repurchase of 1 miltion shares would cost about $\$ 51$ million. In a standstill agreement in October, 1989, firm repurchased $\$ 13.3$ million shares from Nortek.

First City Industries Inc / HB Holdings, subsidiary of Glen Dimplex Lid.

$0.17 / 861009$ (DW)

$590 / 59.8$

Hamitton Beach small appliances / Irish appliance maker

Used to repay debt / 1 / 8K

First City Industries reduced their long-term debt significanthy through the sale of two operating units, including Hamilton Beach.

John Fluke Mfg Co / N.V. Philips

$-0.55 / 870928$ (D)

NA $/ \$ 7.9$

Stock in European subsidiary for sale of electronic equipment / Joint venture

Establishing joint venture $10 / 8 \mathrm{~K}$

This firm and a European firm entered into a joint venture in which each will sell the other's products In their 8rea. The asset sale consisted of the Jahn Fluke's European sales division. Stock repurchase: In December 1986, the firm bought back about $\$ 20$ milion in stock from the Fluke farrily. In November 1987, the firm authorized repurchase of about $\$ 8$ milion. No evidence it was caried out.

General Host Corp (three sales) / (1) Kraft (2) Management (3) American Sait Acquisition Co. (Mgt)

(1) 13.89 (2) -1.48 (3) $8.61 /$ (1) 870604 (DW) (2) 870622 (DW) (3) 880201 (Agreement date)

(1) 595.8 (2) $\$ 39$ (3) $\$ 31 /$ (1) $\$ 87$ (2) $\$ 0$ (3) 50

(1) All American Gourmet Co. (2) Hickory Farms (3) American Salt / (1) Food products (2) Mgmt Group (3) Momt Group

(1) \& (2) Reduce long-term debt (3) Cash for litigation settlement / (1) \& (2) \& (3) $1 /$ (1) \& (2) WSJ (3) BK

In the earty 1980s, General Host began a restructuring away from cyclical dependent industries to focus on retaling. nurseries and crafts. The proceeds from these asset sales were used to reduce debt and were part of the continuing restructuring. Stock repurchases: General Host repurchased about $\$ 21$ million shares in a open-market buyback program in 1986. Through 1987 and 1988, firm repurchased about $\$ 58.6$ million shares on open market. 
Gleason Corp / Diesel Kikj Co

$-5.56 / 890422$ (Agreement date)

$\$ 18 / \$ 7.725$

Differential and gear manufacturing / NA

Strategic, termination of joint venture, selling interest to partner / 0 / Annual report

This asset sale is part of the firm's exit from a falled diversification effort.

Goodyear Tire \& Rubber Co (two sales) / (1) Loral (2) International Paper

(1) 2.51 (2) $2.17 /$ (1) 870122 (DW) (2) 870413 (DW)

(1) $\$ 640$ (2) $\$ 70 /$ (1) NA (2) NA

(1) Aerospace (2) Oil and gas division / (1) Miltary electronics (2) Paper manufacturing

(1) \& (2) Restructuring, reduce debt incurred in repurchase of shares / (1) \& (2) $0 /$ (1) WSJ (2) BK

As part a successful defense to a hostile bid, Goodyear sold severai assets, refocusing the firm on its core tire and rubber business. As part of the defense, the firm repurchased 40 milion shares, financing the repurchase with the sale of all non-tire assets. Stock repurchases: Firm paid approximately \$2 billion for shares repurchased in defensive moves.

Greyhound Corp / Investor group

$4.92 / 861223$ (DW)

$\$ 255 / \$ 30.1$

Bus lines / NA

Not profitable / O / WSJ \& Annual report

Greyhound was unable to profitably cope with deregulation in the bus transportation industry and thus sold its unprofitable bus lines. Stock repurchases: Firm announced plans to buy back up to 8 million shares (\$265 milion) in June and September 1986.

Grow Group / Nippon Oil and Fats

$1.38 / 890713$ (DJ)

$\$ 25.3 / \$ 15$

Paint production assets / Paints and coatings

Reduce debt, general business purposes /1/8K

Grow Group grew in the 1980 s through acquisitions. However, eamings suffered. The asset sale enabled the firm to report a profit and reduce its high debt level.

Gulf Resources \& Chemical Corp / Grace Petroleum

2.62 / 890918 (Agreement date)

$\$ 25 / \$ 0.4$

Oil and gas / Oil and gas

Cash for working capital and environmental costs and penalties / 1 / Annual report

Gulf Resources \& Chemical Corp faced environmental cleanup and liablity costs. To generate cash, the firm sold this and other essets. 
Hamischfeger Corp / Century II, Inc.

$3.10 / 880512$ (Agreement date)

$\$ 76.2 / \$ 59.3$

Construction Equipment Manufacturing / Management Buyout Strategic -sold to MBO / O / BK

The company decided to discontinue the business of its construction equipment division and sold the business to a group of former managers.

Helene Curtis Industries Inc / PTI Holdings Company

$1.85 / 851024$ (DJ)

512.5 / NA

Seakants and adhesives subsidiary / Newly formed holding company

Strategic / 0 / Annual report

The sale of the sealants subsidiary was consistent with Helene Curtis Inc.'s focus on personal care products.

Inspiration Resources Corp (2 sales) / (1) Minerco (2) Cyprus Corporation

(1) 7.79 (2) $-1.10 /$ (1) 851203 (DW) (2) 880701 (D)

(1) NA (2) $\$ 125 /$ (1) $-\$ 10$ (2) $\$ 26.7$

(1) Oil and gas (2) Copper / (1) Mining (2) Mining

(1) Restructuring (2) Repay debt (retired all of bank debt) and general business purposes /(1) 0 (2) $1 /$ (1) BK (2) 8K

(1) Given the poor economic conditions in the natural resources industry, the firm divested operations (purchased only a year earlier) and tried to remake the corporation in a way that significantly improved the prospects for profitability. (2) The firm's attempt to concentrate on agribusiness and away from cycical metal resources continued with the sale of its copper division.

Intermedics / Intermedics Intraocular Acquisition Corp (First Chicago Venture Capital)

-1.84 / 860502 (Agreement date)

$\$ 35 /$ "substantial gain"

Intraocular lens subsidiary / Venture capital group

Proceeds to pay off debt / 1 / Annual report

The intraocular lens division was sold to First Chicago Venture Capital.

International Thoroughbred / Greenwood Racing Ine

$14.79 / 890630$ (Agreement date)

$583 /$ NA

Race track / Race track management - newly formed company

Reduce debt and abtain cash / 1 / Annual report

This financially troubled firm sold its Philadelphia race track to repay debt and obtain needed cash. 
Intemational Technology Corp (two sales) / (1) Tenera, LP (2) GSX Chemical Services

(1) 5.18 (2) $-12.85 /$ (1) 881012 (DW) (2) 890411 (DW

(1) NA (2) $\$ 84.8 /$ (1) NA (2) $\$ 110.1$

(1) Nuclear risk control (2) treatment and disposal division / (1) Services to manufacturing (2) chemicats

(1) \& (2) Strategic (locus on core) $/$ (1) \& (2) $0 /$ (1) \& (2) $8 K$

(1) The sale of the nuclear risk control group is consistent with the continuing effort of the firm to direct its resources into the rapidly growing industrial risk assessment sector. (2) The sale was part of the firm's restructuring program to concentrate on growing subsidaries.

IU International Corp / Paper Corp of America, subsidiary of Alco Standard Corp $5.24 / 860310$ (DW)

$\$ 32.5$ (total cash $\$ 106.7$ with gain from terminating pension plan) / \$21.6 with gain from terminating pension plan

Paper distribution operations / Paper company

Broad restructuring and debt reduction effort / 0 / WSJ (Restructuring seems to dominate debt reduction.)

As part of a broad restructuring effort, IU International sold several operating units, including this, and the bulk of its agribusiness operations and its macademia nut orchands. Over recent years, the restructuring has transformed IU from a complex enterprise serving a multitude of markets into a simpler and smaller company focused on a much narrower range of business activity.

\section{KH Corporation (Fruehauf) / Terex Trailor Corp.}

$18.11 / 890328$ (OW

$\$ 231.3 / \mathrm{NA}$

Trailer manufacturer and shipyard / NA

Pay interest on outstanding debt, repay banks, working capital /1 / WSJ

in 1986, the firm underwent a management buyout. This asset sale was part of the resulting program to restructure the firm and pay down the debt with asset sales.

Keystone Consolidated industries / Fastener Five Acquisitions, Inc -3.08/890116 (Agreement date)

$\$ 16 /-\$ 17.6$

Metal and plastic crafters / NA

Strategic (focus on the core) / O / Financial World, Feb 1990

After losing money for most of the 1980s, the company earned $\$ 9.3$ million in the first 8 months of 1989 after extensive restructuring. 
Kolimorgen / P.C Acquisition Corp

$-3.62 / 860930$ (DW)

$\$ 25 / \$ 5$

Photocircults division / Management group

Strategic 10 / Annual report

As part of a plan to concentrate on new markets in electronics, the firm sold its photocircuits division to a management group.

Koppers Co. I NA

$1.70 / 851213$ (Agreement date)

$\$ 160 /-\$ 100$

Ten different businesses / NA

Use cash for acquisition for construction materials and services operations as well as for repurchase of preferred stock and common slock / 1 / Annusl report

Koppers announcement of the sale of 10 business units refiected its plan to reposition the company to increase eamings growth rate and raise its value to shareholders by concentrating on fts construction materials and services and chemicalbased operations. The proceeds were to be used to repurchase the company's preferred stock and some of its common shares. Stock repurchases: In June 1986, announced plans to redeem comvertible preference shares for about $\$ 46.6$ million. In December 1986, board approved repurchase of about $15 \%$ of common shares for about $\$ 135$ million.

Lee Enterprises Inc / Henry/Benedek Broadcasting

$-3.00 / 860904$ (DW)

$\$ 13 / \$ 10$

Radio station / Broadcasting

Regulation / 0 / 8K

To avold violation of FCC rules against ownership of television and radio stations in the same community, Lee Enterprises sold its ratio station in Omaha after acquisition of a television station there.

Loral Co / Opus Acquisition Corp

-1.14 / 890326 (Agreement date)

$\$ 455 / \$ 5$

Aircraft braking division / NA

Strategic/sale of slower growing division and at the same time acquired a growing division. $/ 0 /$ Annual report

The sale of the aircraft braking division was part of the firm's goal of redeploying assets from slower growth to growing core activities, Including growth through acquisitons. There were alfegations of conflicts of interest in the sale to the firm's Chairman. 
Morgan's Foods Inc / Midwest Restaurants Concepts

$7.58 / 890110$ (Agreement date)

$\$ 3.752 /-\$ 4.013$

Sizzler Restaurants / Restaurants

Sirategic, not profitable / $0 / 8 \mathrm{~K}$

The company sold 11 Sizzler Restaurants that had never achieved projected sales volume and operated at a loss since their acquisition.

National Intergroup Inc (two sales) / (1) Norandahl Inc. (2) Werner Co.

(1) -4.50 (2) $-6.73 /$ (1) 890913 (DW) (2) 891027 (DW)

(1) $\$ 117.7$ (2) $\$ 15 /(1)-\$ 16.45$ (2) $-\$ 2.5$

(1) National aluminum (2) extrusion division / (1) aluminum (2) NA

(1) \& (2) Strategic (concentrate on core) $/(1) \&(2) 0 /$ (1) \& (2) Annual report

These asset sales were part of the firm's exit from eluminum and steel to concentrate on the core distribution business.

S.E. Nichols Inc. / Schreiber Wholesale Services

$11.70 / 890524$ (DJ)

$\$ 21 / \$ 3.5$

Wholesale distribution division / Management buyout

Financial difficulties, need to reduce debt $/ 1 /$ S\&P ASE Stock reports

Nichols sold its F. R. Schreiber Co. subsidiary to a group of management investors. The proceeds were to be used to repay its revolving credit line and for working capital.

Nicolet Instrument Corp / AM Internationa!

$1.41 / 860627$ (DW)

$\$ 22 /-\$ 9.4$

Electronic instrument testing division / NA

Strategic / 0 / Annual report

The firm was unable to operate this division profitably due, in part, to depressed market conditions. Its sale was accompanied by restructuring of the remaining product lines.

Nicor Inc. / Adcor Drilling Inc.

$-0.29 / 860902$ (DW)

NA / NA

Drilling division / Management buyout

Reduce debt through restructuring / 1 / Annual report

Afler two years of sizable losses, the firm relumed to profitability by divesting several unprofitable units, including this drilling division. The proceeds were used to reduce debt. 
Nortek Inc / Duro Industries Inc

$-6.71 / 851230$ (Agreement date)

$520 /-\$ 6$

Textile processing / Management buyout

Strategic / O / Annual report

Akhough the textile processing division remained viable, the firm concluded that it no longer fit into Nortek's long-term plans due to foreign competition and low growth prospects.

O.Sullivan Corp / Vulcan Corp. Jones and Vining

-3.31 / 860604 (Agreement date)

$\mathrm{NA} / 50.15$

Rubber heel and sole operations / Footwear

Strategic / 0 / Annual report

O'Sulfiven Corp decided to get out of the rubber business and concentrate on tts core businesses of vinyl sheeting and injection molding.

Portec / Harsco

$-3.91 / 890206$ (D)

$59.1 / \mathrm{NA}$

Railway maintenance products / Steel/metal works

Cut bank debt (in default) $/ 1 / 8 \mathrm{~K}$

The firm sold its railway maintenance products division and used the proceeds to repay lts outstanding bank debt. The firm had been in default with its creditors until a debt restructuring in August 1988.

Primark Corp / C. Itoh and Co. Ine

$8.51 / 880921$ (DW)

$\$ 37.9 / \mathrm{NA}$

T leasing company / NA

Cash for pending takeover / 0 / WSJ

Primark sold its Telerent Leasing Corporation (providing $W$ leasing to the lodging industry).

Professional Care ine (two sales) / (1) Tender Loving Care Health Service (2) Olsten Corporation

(1) -35.02 (2) $-3.41 /$ (1) 870901 (DJ) (2) 880722 (DJ)

(1) $\$ 3(2) \$ 2.4 /(1) \$ .3$ (2) $\$ .67$

(1) Offices (2) Offices / (1) Health care (2) Temporary services

(1) \& (2) Cash for litigation settlement in medicaid fraud cash / (1) \& (2) $1 /$ (1) \& (2) $8 \mathrm{~K}$

The firm had several years of financial difficulties due to civil and criminal litigation charging medicaid fraud. These sales were part of en asset sale program used to pay fitigation expenses and penalties. 
Punta Gorda Isles Inc / Village Builders of Florida

$17.65 / 851019$ (Agreement date)

$\$ 23 /$ NA

Real estate / Real estate

Repay debt and financial difficulties /1/8K

Weak real estate conditions and a heavy debt burden had resulted in poor performance for this company since 1981. The proceeds from the sale of this marina project were used to further reduce its debt.

Quantum Chemical Corporation / Henkel Corporation

$19.32 / 881228$ (OW)

$\$ 480 / \$ 16.8$

Oleochemicals business / NA

Cash to repay bank loan used to pay dividend / $1 /$ WS.J

This asset sale was part of the firm's unusual recapitalization in late 1988. The firm used the proceeds from the asset sale and a debt issuance to repay a bank ban used to pay shareholders a $\$ 50$ dividend and maintain the ability to continue their acquisition program. Stock repurchase: On 880308 , firm announced a stock buyback plan velued at \$246 to $\$ 273$ million.

Savin Corp / Scriptex Enterprises

$4.82 / 870113$ (D)

NA/ $\$ 1.9$

New York and Long Island retail branches / Retaller

Strategic (focus on the core) and streamline operations / 0 / Annual report

This asset sale is part of the firm's program to streamline operations, focus on the core, increase efficiency and lower its breakeven point. The firm had restructured its debt to get out of default in the previous year.

Service Resources Corp (two sales) / (1) U.S. Banknote Company (2) Thomas L. DePetrillo

(1) -4.94 (2) $13.14 /$ (1) 880829 (DW) (2) 890406 (D)

(1) $\$ 7.6(2) \$ 3.2 /(1) \$ 19.1$ (2) 2.036

(1) Financial printing company (2) Keyboard manufacturing / (1) Financial printing (2) Management buyout

(1) \& (2) Financial difficulties \& pay down debt / (1) \& (2) $1 /$ (1) WSJ (2) $8 \mathrm{~K}$

This financially troubled firm (in default on interest payments since 1987) sold these assets in an attempt to remain solvent.

Sierracin Corp / Valor Electronics Inc $7.12 / 860607$ (Agreement date)

$\$ 2.3 / \$ 0$

Power systems division / Electronics Strategic / 0 / Annual report

The firm sold this asset to concentrate on growth-oriented businesses and core technologies. 
Talley industries Inc / TRW

$-16.93 / 890206$ (DW)

$\$ 85 / \$ 37.5$

Air bag divtsion / Industrial

Cash earmarked to repay debt / 1 / WSJ

The sale of the air bag division culminated the firm's two-year restructuring program of divestments and acquisitions.

Tandy Brands Inc (2 sales) / (1) Action Inc and D. Motsenbocker (2) Grate Home and Fireplace Co (1) -2.47 (2) $12.20 /$ (1) 860410 (D.) (2) 870304 (DJ)

(1) $\$ 3(2) \$ 1.6 /(1)-\$ 0.88(2)-\$ 9.3$

(1) Westem leather division (2) Grate and fireplace otivision / (1) NA (2) Home supplies

(1) \& (2) Strategic / (1) \& (2) 0 / (1) \& (2) Annual report

These sales were part of the company's restructuring program designed to enable the firm to concentrate resources on its remaining rapidly growing speciality retailing division.

Morton Thiokol / Dow Chemicals

$-11.86 / 841115$ (DW)

$\$ 131 / \$ 75.1$

Household cleaner division / Chemicals

Strategic (focus on the core) / 0 / Annual report a WSJ

The sale of the household cleaning division to Dow Chemical for cash and the shares of the firm held by Dow helped the firm concentrate on its other businesses and served as an antitakeover device against Dow (the sale was accompanied by a 10-year standstill agreement).

Total Petroleum Ltd / Various buyers

$2.98 / 890104$ (DW)

$\$ 152 / 52$

Oil and gas / NA

Strategic / 0 / Annual report

The oil and gas operations in the U.S. did not offer sufficient prospects for future profitability.

Tridex Corp / Jordan Industries Inc

B.05 / 890803 (D)

$59.9 / \mathrm{NA}$

Radio coaxial connectors division / NA

Redeem notes, working capital and acquisitions / 1 / WSJ

The firm used the proceeds to to pay in full its outstanding indebtedness of \$6.7 million to Heller Financial and terminated its credit facilities with Heller. 
Tribune Co / Cooke Media Corporation

$1.66 / 851210$ (DW)

$\$ 176 / \$ 176.7$

LA Daily News (newspapers) / Communications

Retire debt / 1 / WSJ

The proceeds from this sale plus the sale of four cable systems were used to retire debt which had been incurred in the acquisition of a Los Angeles TV station.

Union Carbide Corp / Ratston Purina

$4.86 / 860407$ (DW)

$\$ 1415 / \$ 304$

Battery products division / Diversified company

Proceeds over the book value of essets were distributed to shareholders as epecial dividend (about \$33.20 per share) / $1 /$ WSJ

These asset sales were part of Union Carbide's restructuring as a defense to a hostile bid from GAF. In the restructuring. the firm repurchased $56 \%$ of tits shares for cash and debt and paid a large cash dividend to shareholders. Stock repurchases: To ward off GAF, paid out \$774.6 million in cash plus about \$2.6 billion in debt for $56 \%$ of shares. Atso paid out proceeds from sale of unit to shareholders as special dividend.

United Inns Inc / Hanna Car Wash

$-0.84 / 880812$ (D)

$\$ 17 / \$ 2.2$

Car wash business / Car wash

Not profitable / $0 /$ Annual report

This firm sold its unprofitable discontinued car wash division.

U S Shoe Corp (3 sales) / (1) Edison Brothers Apparel Stores (2) Freeman Shoe Co (3) Linen Supermarket (1) 1.31 (2) 0.55 (3) 0.38 / (1) 870429 (DW) (2) 870511 (Agreement date) (3) 870609 (Agreement date) (1) $\$ 44$ (2) $\$ 41$ (3) $\$ 4.6 / \$ 7$ on all three combined

(1) J Riggings (retailing) (2) Mens Shoe Division (3) Horne Front Division / (1) Shoes (2) Shoes (3) Home products

(1). (2) \& (3) Strategic / (1). (2) \& (3) $0 /$ (1). (2), \& (3) Annual report

US Shoe sold a chain of apparel stores, its home products division and its mens shoe division to fund expansion of specialty retailing and optical retaiting. as weil as selective footwear opportunities. 
Varo Inc. / Varo Quality Semiconductor Inc

$-0.30 / 851224$ (OW)

$\$ 14.8 / \$ 2.2$

Serriconductors / Management group

Unprofitable division - proceeds earmarked to repay $\mathbf{5 7}$ million of short-term debt with remainder for working capital purposes / 1 / S\&P Stock reports

Varo sold its unprofitable semiconductor manufacturing subsididary and earmarked the funds to repay debt. Stock repurchases: Firm authorized repurchase of about $\$ 1$ miltion of common stock on open market.

Vermont Research Corp / Mittope

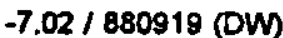

$52.85 / \$ 1.5$

Disk drive manufacturing / Computer

Unprofitable division / 0 / S\&P ASE stock reports

Disappointing sales of a new disk drive led to the sale of a disk drive production facility and related technology.

Wamer Communications Inc / American Protection Industries, Inc $0.37 / 841213$ (DW)

\$162 / NA

Franklin Mint (Collectible manufacturing) / Newly formed partnership - Wamer Cornmunications retains stake Strategic - build upon continuing operations and improve balance sheet / 0 / Annual report

Wamer Communications sold several businesses reduce corporate overhead and refocus attention on its core businesses. Stock repurchases: Announcement on 840319 that firm would buy back Rubert Murdoch's News Corp.'s shares for $\$ 180.6$ million, ending 15-week struggle for company.

Warner-Lambert Co (three sales) / (1) Becton Dickinson \& Co. (2) Cambridge Instrument Co (3) Henley Group inc

(1) 1.47 (2) 5.61 (3) $-2.45 /$ (1) 860306 (DW) (2) 860326 (DJ) (3) 860425 (DW)

(1) $\$ 225$ (2) $\$ 50$ (3) $\$ 163.5 /-\$ 497$ on all three combined

(1) Hospital products division (2) Scientific instruments division (3) imed / (1) Health care (2) NA (3) NA

(1). (2), \& (3) Restructuring to focus on the core / (1), (2), \& (3) $0 /$ (1), (2), \& (3) 8K

As part of a review of operations and the changing business environment in the hospital supply industry, Wamer-Lambert mede the decision to write down and divest certain of its operations and to restructure and consolidate others. Stock repurchases: WSJ reports on 851129 that firm plans to buy back 8 million shares. for about $\$ 352$ million. 


\author{
Westinghouse Electric Corp / Group of 5 telecommunications companies \\ $-1.51 / 851223$ (DW) \\ $\$ 1700 / \$ 500$ \\ Cable company / Telecommunications \\ Restructuring $10 / 8 \mathrm{~K}$
}

This sale is part of Westinghouse Electric Corporation's restructuring program designed to promote growth as the leading participant in several markets. Stock repurchases: By March 1986, firm had repurchased about 21 million shares for about $\$ 887.25$ million. 